\title{
XXXVII
}

\section{"Well of English Undefiled" \\ 1877}

(LETTERS 2452 TO 2548)

ENTERING HIS EIGHTY-THIRD YEAR, Bryant showed little diminution of vigor, either mentally or physically. One of his newspaper's editors recalled that he disdained to take a cab from the East River ferry house to his office when coming in from Roslyn, and continued to walk nearly three miles each way from his home on West Sixteenth Street when in town. After the Post moved to its new building in 1875 he often shunned the elevator, climbing the stairs to his ninth floor office instead. At Cummington in mid-summer he took long rambles, often with his brother John and sometimes with Arthur Bryant, over hills and woods, and across the Westfield River, searching out old graveyards and cellar holes, boyhood haunts, and blooms he had seen in past seasons. The "Bryant boys," as some of their neighbors termed them, presented striking figures as they trudged along in their white summer suits, beards streaming in the wind. Sometimes Cullen would be seen to put a hand on the top rail of a fence and vault over it. His robust health and energy were so widely renowned that he was induced by the owner of Popular Science Monthly to permit publication for wide reading of a letter in which he had earlier recounted his habits of diet and exercise.

Although Bryant was not often now at the Evening Post's editorial desk, he pursued his other literary tasks steadily, making public appearances with an assiduity equaling his bodily agility. As in the past, he was rarely inclined to compose occasional verses. His response to one request, that for an ode commemorating the Battle of Oriskany, was characteristic: "If I were to employ myself in such an office, I am afraid that I should appear like a gardener, who, in the beginning of winter, should attempt to raise flowers in the open air, in order to have a bouquet ready for the festivities of a New Year's Eve." Yet there were exceptions. He contributed to the centennial celebration of the Battle of Bennington, Vermont, verses which might later be inscribed on the towering obelisk to be erected there in commemoration. He wrote lyrics for a Methodist hymnal, and was amused that the hymnologist who had asked for them should call these the "best temperance hymn which was ever written or ever will be, until I write another." And he was induced to write a sonnet in memory of the historian John Lothrop Motley, whose removal from his ministry to Great Britain by President Grant in 1870 Bryant had criticized sharply. But he did not feel up to composing verses to mark the seventieth birthday of Whittier, "a poet whose life is as beautiful as his verse," Bryant wrote in answer to an invitation. 
In his late years Bryant had been drawn toward a re-examination of seventeenth-century English verse. In 1872 he had written for the magazine Old and New an essay on the poetry of John Oldham. Now in 1877 he gave the North American Review an article on that of Abraham Cowley.

Of the few requests Bryant complied with this year to give public addresses, there were two which appealed to him especially. In May in Central Park a statue was unveiled of his late friend the poet Fitz-Greene Halleck, and Bryant, chairman of the sponsoring committee, gave the oration at the ceremony, which was crowded almost beyond the ability of the police to control because of the presence of President Hayes. Another event of personal gratification was his visit in June to Lafayette College at Easton, Pennsylvania, for its commencement. The college awarded an annual prize for the study of an author, who that year had been Bryant. The text used in the course was Studies in Bryant, written by a long-standing friend, Joseph Alden, formerly a professor at the college. The prize, a set of Bryant's writings, was presented by its author to a graduate who would later become a prominent philologist. Bryant was pleased to dine, among others, with Alden, as well as a future president of the United States, General Benjamin Harrison, whose son was then graduating.

Among honors Bryant declined this year were the presidency of the American Red Cross, then in the process of formation, and of a "Law and Order League," which he had been inclined toward accepting until he heard that it was in conflict with a rival group. He was pleased to learn that several more literary clubs had been named for him, although he felt he could do no more than accept honorary membership in them. And, although he was unable to attend a testimonial to the sculptor William Wetmore Story, by whom he had been entertained at Rome in 1858, his name led a published list of prominent New Yorkers signing the invitation to Story.

In his introduction to A Library of Poetry and Song Bryant had stressed the importance to a writer of what he termed a "luminous style." His own preeminence in this respect was often praised by his fellows. Walt Whitman spoke of the "marvelous purity of his work in verse, ... never a waste wordthe last superfluity struck off; a clear nameless beauty pervading and overarching all the work of his pen." A political opponent remarked that he couldn't decide whether he hated or admired Bryant's editorials the more, for while he "detested" their "inculcations" he was charmed by the "beauty and vigor" of their style.

Bryant was impatient with heightened speech, or "fine" writing. Once, when his spinster friend Eliza Robbins, who had occupied the Bryants' home during their absence, reported that "the mechanic has returned your chair, and expressed the hope that its equilibrium has been properly adjusted," he demanded to know what had really been said, forcing the admission, "Well, if you must know, he said he guessed the rickety old concern wouldn't joggle any more." He denigrated the "hackneyed phrases" and "awkward distortions of those who thought that by putting a sentence out of its proper shape they were writing like Milton." He instructed new Evening Post reporters in the 
accurate use of words, listing for their guidance in an Index Expurgatorious terms of facile coinage, and proscribed such imprecise diction as "commence" or "inaugurate" for "begin," "endorse" for "approve," and "parties" for "persons."

As Bryant read through Gay's chapter drafts of the Popular History, he gave his collaborator a course in diction and usage, with the admonition, "It seems to me that a neat style in history would bear reading aloud without the hearer missing the sense." For it was apparent to him-as soon proved the case-that the work would be generally thought to be the product of his pen. He wished that this work, standing as his last major composition, should reflect his lifelong concern with stylistic clarity.

With the second volume of the History ready for printing by the early months of 1878, half of the publication had passed under Bryant's scrutiny. That he expected to oversee the work's completion was evident in the fact that, though this volume concluded with the year 1740, he was already busy writing a chapter on the progress of literature, the arts, and sciences up to the year 1776 . This chapter, if completed, did not find a place in the finished work. 
2452. To Parker C. Chandler ${ }^{1}$

Dear Sir.

New York, January 4th 1877.

I thank the Executive Committee of the Williams Alumni Association of Boston for the invitation, which you have politely communicated, to attend their tenth annual dinner. ${ }^{2}$ I cannot come, but I send the expression of my wish that the foster-children of Williams in Boston may continue to eat their pleasant dinners as long as Boston stands. The Spaniards often conclude a letter with the compliment, "May you live a thousand years." In concluding this letter I say "May the Alumni of Williams in Boston eat a thousand annual dinners, and then begin the next thousand with an undiminished appetite."

$$
\text { I am, sir, }
$$

faithfully yours,

W C BRYANT.

MANUSCRIPT: American Antiquarian Society AdDress: Parker C. Chandler Esq / Secy of the Executive Com ${ }^{\text {tee }}$.

1. Identified only as in descriptive note.

2. The invitation is unrecovered.

2453. To C. N. Cordner ${ }^{1}$

New York January 8th 1877.

Dear Mrs. Cordner.

I am generally in the Office of the Evening Post at twelve o'clock M. I will be there on Tuesday and Wednesday at that hour if you choose to call on either day and will talk about the "thoughts" of which you speak.

Yours truly

W C BRYANT

P.S. I remember that you once brought me several poems-but I know not what has become of them. W. C. B.

MANUSCRIPT: HCL ADDRESS: Mrs. C N Cordner.

1. Unidentified.

2454. To O. D. Norton ${ }^{1}$

Dear Sir.

New York Jan. 8th 1877.

The poem of which you sent me a copy, is no great matter-but I am sure that it is very correctly transcribed. I had forgotten it entirely, 
but on reading it, the lines come back to me as fresh as if they were written yesterday. It is not the first attempt which I made to write poetry, but was probably produced when I was eleven or twelve years old-perhaps earlier. I remember that a poem of mine, a school exercise, was published in the Hampshire Gazette, at Northampton. That was written when I was ten years old, and perhaps this is the one. $^{2}$

Yours respectfully

W. C. BRYANT.

MANUSCRIPT: Cincinnati Historical Society ADDREss: O. D. Norton Esq.

1. Unidentified.

2. Attached to this letter are 26 heroic couplets, presumably in Norton's holograph, beginning "When the dire strife with Briton's power unfurled." This poem, which Bryant had recited as a school exercise, had been published in the Hampshire Gazette in Northampton on March 18, 1807, under the caption, "A Poem. Composed by a lad of 12 years old, to be exhibited at the close of the winter school, in the presence of the master, the minister of the Parish, and a number of private gentlemen." It was reprinted in the $E P$ on June 12, 1878, the day of Bryant's death, in a long account of his life.

2455. To Messrs. Harper \& Brothers ${ }^{1}$

Gentlemen

The Evening Post,

Broadway and Fulton Street.

New York, January 18, 1877

Will you do for me the favor to send me by the bearer a copy of the work entitled The First Century of the Republic. ${ }^{2}$

Yours respectfully

WM C BRYANT.

MANUSCRIPT: UVa ADDRESS: To Messrs Harper \& Brothers. ENDORSED: Sent Jan. 18/ 73.

1. New York publishers who had printed a volume of Bryant's poems in 1836, and others of his writings. See 318.2.

2. Not further identified.

2456. To Leonice M. S. Moulton

Dear Mrs. Moulton,

The Evening Post,

Broadway and Fulton Street. New York, January 181877.

I should have mentioned this morning that I sent a letter addressed to you, ${ }^{1}$ yesterday, to the post office before I received your 
note. I supposed that you had already arrived at Roslyn. It is my intention to come out as soon as the snow which encumbers the roads is melted off-which generally happens before the winter is over. I want to look at some of my books in Roslyn in order to obtain some hints for a chapter, in the Popular History, relating to American Literature-that is to say the literature of the United States. You say nothing of going to Baltimore, and I should like to be certain that you will be in Roslyn when I come out. If your grand daughter's nuptials are to take place this winter you will go of course. I suppose that the whole region about Roslyn is now deep in snow and that the moment we have a south wind and a soft temperature the slush will be knee deep.

I was glad to see you looking so well this morning and hope that the return of your health will be permanent. You have only to remember that you are not quite as young as you once were and that it behooves you to be a little prudent. ... .

MANUSCRIPT: MdHS.

1. Letter unrecovered.

2. Conclusion clipped, with a note added, probably by Josephine Stewart, "Signature given to an autograph collector."

2457. To William J. Linton ${ }^{1}$

Dear Sir.

The Evening Post, Broadway and Fulton Street.

New York, January 201877.

You are welcome to the use which you propose to make of the poems mentioned in your note. ${ }^{2}$

Yours respectfully, W. C. BRYANT.

MANUSCRIPT: YCAL ADDRESS: W. J. Linton Esq.

1. William James Linton (1812-1897), a British wood-engraver, worked in the United States after 1866. In 1892 he published The History of Wood-engraving in America.

2. Unrecovered. Linton illustrated a gift edition of Bryant's The Flood of Years, which Putnam published in 1878, and contributed sketches and engravings to the first volume of Bryant's Popular History.

2458. To the Brooklyn Historical Society

Friday Morning Jan. 26, 1877

Mr. Bryant regrets that a previous engagement in the city of New York, for Wednesday next, prevents him from accepting the polite 
invitation of the Brooklyn Historical Society to their Annual Dinner on that Evening. ${ }^{1}$

MANUSCRIPT: Long Island Historical Society DOCKETED: Bryant, $\mathrm{W}^{\mathrm{m}}$ Cullen / January 26th. 1877-.

1. Invitation unrecovered.

2459. To John Taylor Johnston ${ }^{1}$

My dear sir.

New York January 30?² 1877.

Enclosed is a letter to Tiffany \& Co. authorizing the removal of the Bryant Vase to the Metropolitan Museum. I should like some paper the purport of which should be that the vase is my property. If, after the removal is effected, you would write a note to this effectthat the vase is deposited among the objects of art in the Metropolitan Museum, subject to my order as owner, or that of my legal representatives-you would much oblige me. This, if the question should ever come up, would show to whom the vase belongs. ${ }^{3}$

Yours faithfully

W. C. BRyant.

MANUSCRIPT: NYPL-GR (draft); MMA (final) ADDREss: John Taylor Johnston Esq.

1. Johnston (1820-1893), a railroad executive and art collector, was the first president of the Metropolitan Museum of Art, of which Bryant had been a founder and first vice-president.

2. Bryant apparently misdated the final draft of this letter as "Jany 15." The initial draft bears the date January 30, and Bryant's endorsement, "To John Taylor Johnston / My Letter.- / Jan 30 1877-"

3. Bryant later released title of the vase to the museum; see Letter 2477.

2460. To John Marshall Stone ${ }^{1}$

The Evening Post, Broadway and Fulton Street. New York, February 5th 1877

Sir. A meeting has been held in this city for a purpose in which your State, as well as several others, is interested. I take the liberty of sending you, along with this note, a pamphlet containing a report of the proceedings. ${ }^{2}$ A committee of disinterested persons-men of high character-was appointed to carry into effect the purpose of the meeting. Should your State think proper to enter into an understanding with the committee, I would suggest that in order to secure its full 
benefit, there be no interference permitted from any quarter governed by a private or special interest. I am, sir, with great regard.

Your ob Servt

W. C Bryant.

Chairman of the Meeting.

MANUSCRIPT: Mississippi Department of Archives and History address: To His Excy John M. Stone. / Governor of Mississippi / Jackson, / Mississippi. DOCKETED: Wm Cullen Bryant. / NY / Feb 5/77.

1. Stone (1830-1900), formerly a Confederate officer, was governor of Mississippi from 1876 to 1882 , and again from 1890 to 1896 .

2. This report is unrecovered. The date and subject of the meeting are uncertain.

2461. To John R. Howard ${ }^{1}$

New York, Feb 201877.

Dear Sir.

Is it too late to correct the statement that the author of The "Old Continentals" was born in England? See the enclosed from the Evening Post of today-2

Truly yours

W C BRYANT

MANUSCRIPT: Presbyterian Historical Society ADDREss: Jn ${ }^{\circ} \mathrm{R}$ Howard Esq.

1. Possibly the same correspondent as John E. Howard; see Letter 2408.

2. A note in the EP of that date identifies the author in question as Guy Humphreys McMaster (1829-1887), born at Clyde, New York, a New York jurist and poet, and the author of "A Dream of Thanksgiving Eve" (1864), on the occasion of the people of some Northern states having sent a quantity of turkeys to the Union army before Petersburg for Thanksgiving dinner.

2462. To Leonice M. S. Moulton

The Evening Post, Broadway and Fulton Street.

Dear Mrs. Moulton.

New York, Feb. 21, 1877.

Did you send me the printed scrap to persuade me that I am eighty four years old when you know that I am but eighty two? But there is a time for all things and there will be a time for eighty four if I should live.

Yes certainly, if you are disposed, go to Cummington and take the Commissioner along with you to set the wits of the Cummington people as you would set a clock. But let me know when you go. I send 
you back the letters from Cummington and Troy. The other day I had a pull down in the shape of an indigestion, having dined out. On Friday I kept within doors. Tomorrow I go to the Harvard dinner ${ }^{1}$ but I shall keep guard strictly at the doors of the stomach excluding all that may create a disturbance. Kind regards to Miss Holmes and to the Professor. ${ }^{2}$

$$
\begin{aligned}
& \text { Yours truly } \\
& \text { W C BRYANT }
\end{aligned}
$$

MANUSCRIPT: HEHL ADDRESS: Mrs. L. M. S. Moulton / Roslyn / Queens Co. / Long Island POSTMARK: NEW YORK / FEB / 21 / N. Y.

1. Bryant's attendance at Harvard College alumni functions was by virtue of his election in 1817 to membership in the Harvard chapter of Phi Beta Kappa. See Letter 68 . This dinner was reported in the $E P$ on February 23.

2. In writing Mrs. Moulton, Bryant's references to the "Professor" and the "Commissioner" are to her adopted son Dr. John Ordronaux. Miss Holmes was apparently Mrs. Moulton's companion.

2463. To H. B. Griggs ${ }^{1}$

Dear Madam.

New York March 8th 1877.

Mr. Justin Hickson Olds, concerning whom you inquire, ${ }^{2}$ married a sister of mine, as you suppose. She died some six or eight years since in Peoria, ${ }^{3}$ Illinois, leaving four grownup children, a son and three daughters. The youngest daughter died, the son and one of the other daughters married and are living; the other daughter remains single. Mr. Olds has married again. Mr. Olds has always had the respect of the community in which he lived, but has never been very fortunate in getting money.

Looking over what I have written, it occurs to me that possibly the youngest daughter died before her mother. ${ }^{4}$

P.S. Mr. Olds lives yet in Peoria.

$$
\begin{aligned}
& \text { I am, madam, } \\
& \text { respectfully yours. } \\
& \text { W. C. BRYANT. }
\end{aligned}
$$

$$
\text { W. C. B. }
$$

MANUSCRIPT: NYPL-BG ADDRESS: Mrs. H. B. Griggs.

1. Unidentified.

2. Bryant's brother-in-law; see Volume I, 12.

3. Charity Louisa Olds had died ten years earlier.

4. Charity Olds' youngest daughter, Lucy Wood Olds, died in May, 1868, at the age of nineteen, five months after her mother's death. 
2464. To John Howard Bryant

Office of The Evening Post No 208 Broadway

New York, March 9th. 1877

Dear Brother.

I have not written to you since I received your account of the matters of mine which you have in charge ${ }^{1}$-but I need not tell you that. I have often thought of writing to thank you for the trouble you have taken, and the judicious manner in which you have managed my affairs in Illinois-and this I do now. I hope it will seem to you better late than never.

Here in New York the condition of the Evening Post is improving somewhat. Since we cheapened the paper, allowing it to be sold for three cents, its circulation has increased by some three or four thousand. There has been a deplorable falling off in the advertising but this is growing a little better though it will be long probably before it reaches the old mark of five or six years ago. My own literary interests are not in a bad condition, the translations of the Iliad and Odyssey in the hands of J. R. Osgood \& Co. still find a market and the new edition of my poems, published by the Appletons has sold beyond expectations. ${ }^{2}$ All that were printed were soon disposed of and this day they rendered me an account in which I was credited with eleven hundred dollars.

I suppose that you were disappointed in the result of the contest for the Presidency. I confess that it seemed to me from the first that Tilden would win and I could hardly help expecting after the Electoral Commission was appointed that something would happen to throw the office into his hands.

I think you will find that Hayes will make a better president than you probably expect. He has already incurred the opposition of the worst men among the leaders of his party, and if he stands out firmly against them, there is a chance that there will be a new formation of parties. But that is a matter concerning which it is perhaps too soon to speculate.

We are all well. Anna is to be married to a young man from Boston now living here named Poor-a very good young man they say. ${ }^{3}$ Julia sends love. Remember me kindly to all.

Yrs. affectionately

W C BRYANT

MANUSCRIPT: Maine Historical Society AdDRESS: John H. Bryant Esq.

1. This account is unrecovered. 
2. The last collection, published by Appleton, to appear during Bryant's lifetime; referred to herein as Poems (1876).

3. If, as seems apparent, Bryant refers here to his wife's niece Anna Fairchild, this marriage was not performed, for Anna remained single and was Julia Bryant's inseparable companion after Bryant's death. She was a contingent beneficiary under Bryant's will; see Bigelow, Bryant, p. 346.

2465. To Oscar H. [Hanbyer?]

Dear Sir.

New York March 9th. 1877.

Allow me through you, as President of the William Cullen Bryant Club, to thank the members of that association for the honor they have done me in taking my name. The objects they have in view are of a most important nature, and it is my hope that in the pursuit of them they will look to better examples than his whose name they bear, and in after life experience the full advantage of a sedulous cultivation both of the intellectual and moral nature.

I am, dear sir, faithfully yours.

W C BRYANT

MANUSCRIPT: NYPL-GR (draft) ADDREss: Oscar H. Han[byer?].

2466. To an Unidentified Correspondent

New York, March 15th, 1877.

Dear Sir,

You are invited to meet a few gentlemen of the City at Delmonico's, (Fifth Avenue and Twenty-sixth Street), on Thursday Evening, $22 \mathrm{~d}$ inst., at 8 P.M., to consider the question of establishing a Soldiers' Home in the State of New York.

This State sent over four hundred and eighty thousand men to the late war, and yet, to-day, there is not within her borders, a spot where the disabled and indigent veteran can find a home, save in the County Poor House.

Some months since, a movement was inaugurated by the "Grand Army of the Republic," to supply this want. By private subscriptions, and through the aid of public meetings, held in various parts of the State, nearly forty thousand dollars have been raised, the City of Brooklyn alone subscribing fourteen thousand dollars at one meeting.

The New York Soldiers' Home has been incorporated by the Legislature, a large farm has been purchased at Bath, Steuben County, and plans have been matured for erecting upon the grounds buildings suitable for the accommodation of all the indigent, disabled veterans 
of the State. It is estimated that they number about eighteen hundred, nearly two hundred of whom are in the County Poor Houses, and the remainder are inmates of institutions in other States.

The cost of completing the buildings, and putting them in order for occupation, will be about sixty thousand dollars, in addition to the money already raised.

It is intended to hold a public meeting at the Academy of Music on the evening of April 17th, to lay this matter before the public. At such meeting General Sherman is expected to preside, and it is proposed to have appropriate addresses from some of our leading citizens.

The meeting to which you are now invited, is called for the purpose of obtaining the advice and co-operation of the principal gentlemen of the City preparatory to the public meeting in aid of this movement. We trust that it will recommend itself to your approval. ${ }^{1}$

We are, Yours truly,

William C. BRYANT and others ${ }^{2}$

MANUSCRIPT: New York State Library.

1. On March 23 the EP reported a meeting at Delmonico's Restaurant the previous evening to raise funds to establish a New York State soldiers home at Bath, in Steuben County, New York. Bryant was chairman pro-tem, appointing in turn General John A. Dix (388.8) because he was a soldier. On April 18 the newspaper reported a similar meeting on April 17. The home was soon established with the assistance of the veterans organization, the Grand Army of the Republic, and in 1878 the state assumed responsibility for its maintenance. See David M. Ellis et al., A Short History of New York State (Ithaca: Cornell University Press [1957]), p. 342.

2. This printed letter bears the names, besides Bryant's, of the New York manufacturer and philanthropist Peter Cooper (1791-1884), John A. Dix (388.8), New York Supreme Court Justice Noah Davis (1818-1902), and Douglas Campbell and John F. Henry, officers of the Grand Army of the Republic.

2467. To Isaac Henderson

New York March 16, 1877.

My dear sir.

I do not find that I am able to make clear to my daughters the precise situation of my affairs, more especially those which relate in any way to the Evening Post, and the Job Office. I have therefore yielded to their desire to appoint Mr. Andrew H. Green my Attorney ${ }^{1}$ to act in my place, which you will understand is done without any unfriendly [intent?] or an apprehension of any interruption of the good understanding which has subsisted between us. ${ }^{2}$

Yours truly

W. C. Bryant. 
MANUSCRIPT: NYPL-GR (draft) ADDRESS: To Isaac Henderson ENDORSED (by Bryant): Letter to Mr. / I. Henderson- / March 16, 1877.

1. Andrew Haswell Green (1820-1903), law partner of Samuel J. Tilden and, from 1871 to 1876 , comptroller of New York City and a man with the reputation of great integrity.

2. Parke Godwin's long-held distrust of Isaac Henderson, which had led him in 1870 to term Bryant's principal partner and business manager "a most subtle, adroit, and thorough rascal," finally persuaded Bryant to permit reluctantly a formal examination of the EP's affairs. This resulted early in 1878 in a report which largely confirmed Godwin's suspicions that Henderson had for some time been systematically appropriating his partner's funds to his own uses. See Letter 1910; Nevins, Evening Post, pp. 420-434; manuscript "Statement of Bonds, Mortgages etc. \& Affairs of Office made by Judge Monell March or April 1878," NYPL-BG.

2468. To Henry W. Bellows

\section{Dear Doctor.}

I found myself without money yesterday, after your persuasive discourse, which would have drawn "iron tears down Pluto's cheek," if he had been there to hear it. As you did not tell your audience to whom they were to send their contributions, in case they came to church unprovided, I have ventured to send enclosed a ten dollar bank note to you. If that gives you any trouble, please send it by the bearer to its proper destination and oblige.

Yours faithfully

W. C. BRYANT.

MANUSCRIPT: UVa ADDRESS: Dr. H. W. Bellows.

1. John Milton, Il Penseroso, 1. 107.

2469. To Harriette E. Hart ${ }^{1}$

New York March 19th 1877.

Dear Mrs. Hart.

I am sorry to have defaced your paper as I have done-barbuiller ${ }^{2}$ as the French say, but I think that you will be able to make out what I meant by it. Your idea of the inscription is very good and appropriate. I have filled out the blank space on the fourth page with what I think is just to General Wool. ${ }^{3}$ Mrs. Wool's virtues were of a modest and domestic character and are therefore mentioned more generally. I hope this will satisfy you or at least, if you do not adopt what I have written will lead you to think of something better.

$$
\begin{aligned}
& \text { I am, madam, } \\
& \text { very truly yours } \\
& \text { W C. BRYANT. }
\end{aligned}
$$


MANUSCRIPT: UVa ADDRESS: Mrs. Harriette E. Hart.

1. Unidentified.

2. Literally, to daub, or besmear. The nature of this "paper" is uncertain.

3. John E. Wool (563.3). No publication on General Wool by Mrs. Hart has been identified.

2470. To Leonice M. S. Moulton

New York March 19th 1877.

Dear Mrs. Moulton.

I hope the dinner agreed with you-in a physical and material sense I mean. But you must be on your guard against the seductions of the lady in scarlet. The stomach is the weak part with some people, and the approach of the enemy on that side is full of danger. When Hector had the famous interview with Andromache she entreated him to remain within the walls and defend an exposed place where a wild fig tree grew and the walls were low, instead of going out to meet the enemy. ${ }^{1}$ I give you a similar piece of advice.

As for Mrs. Norton whose marriage you speak of, I cannot say that $\mathrm{I}$ am surprized at it. ${ }^{2}$ There is nothing too absurd to happen in the way of marrying. But it must have been a love match, for I never heard that the lady was rich. She is a poetess too, and one of a pretty high class, and poetry you know leads people to do very foolish things sometimes. The principal objection to the match is that it brings her wedding too near her funeral. Yet that may be an advantage in an economical point of view-

- The funeral baked meals may coldly furnish forth the marriage tables. $^{3}$ No-that cannot be, for the wedding comes first-and my quotation goes for nothing - Let us have a new reading-

- The wedding cakes when cold may furnish luncheon for the funeral guests.

I see you are hankering for the house on Beacon Street and the carriage. But what if the gentleman should not propose[?] ${ }^{4}$

The weather has become suddenly so cold that I fear it betokens a postponement of the birth of the violets. I want to come out to Roslyn with the earliest appearance of those fragrant white ones which cover the border at the front of my house. You should have-perhaps you have already some of them near your door. They love the spots where the grass is thin or the ground broken, or where the ground is shaded in summer and open to the sun in the Spring.

Excuse this blotted sheet, which is not half as bad as the scrawls which George MacDonald the author of so many popular novels ${ }^{5}$ used to send when he was in this country in answer to invitations of various 
kinds. And then you can read what I write without difficulty which is more than could be said of his manuscript. Regards to Miss Holmes and the Doctor if he is with you.

Yours faithfully

W. C. BRyant.

MANUSCRIPT: NYPL-Bryant-Moulton Letters ADDRESS: Mrs. L. M. S. Moulton.

1. Homer's Iliad, Bryant's translation, VI, 555-558.

2. British poet/novelist Caroline E. S. Norton (1808-1877). After the death of her first husband, from whom she had long been estranged, she married Sir William Stirling-Maxwell, ten years her junior, and died the same year.

3. Cf. Hamlet, I, ii, 180-181.

4. Mrs. Moulton's husband had died in 1875 . Evidently she did not remarry.

5. See Letter 2137.

2471. To the Committee of the Century Club on Admissions.

New York March 27th 1877.

Gentlemen.

I take pleasure in seconding the Application of Professor Elwin Waller of Columbia College to be admitted as a member of the Century. ${ }^{1}$ His personal character, manners and attainments are such as will make him a most desirable member.

I am, gentlemen

Yours faithfully

W. C. BRYANT.

MANUSCRIPT: PUL AdDRESS: To the Committee of the Century Club on Admissions.

1. The records of the Century Association indicate that Waller was not admitted to membership until November 27, 1889. He was then sponsored by James K. Ford and Ogden Rood.

2472. To John Howard Bryant

Office of The Evening Post Corner of Fulton and Broadway New York, March 28th 1877

Dear brother.

You complained, in your last letter to Julia, that I did not answer your letters. I therefore answer your last as soon as I get it. It came only today. I have been very busy for a considerable time past in writing a chapter of the "History" treating of the progress made in our country, in Literature, in the Arts and in Science up to the year 1776, when we broke away from Great Britain, and I found it a work of some labor. ${ }^{1}$ There was a good deal of reading to be done, and a 
looking up of facts and dates, and then a good deal of thinking. So I did not always answer the letters that did not seem to require immediate notice.

Your claim, that you have managed my money matters in Illinois with a careful attention to safety, is perfectly just. You have done better than I should have done. I have not often been cheated; the dealings of my fellow men with me have in the main been just and fair, but they have not always paid me what they owed me-borrowed money, I mean-and the reason I think, in every case, was that they had not the money to return to me.

You have the measles prevalent in your region; we have here pneumonia which is very often fatal, and carries people off with great suddenness. The dip[h]theria prevails also, and attacks domestic animals, dogs and cats. Our Milton had a turn of it and ate nothing for several days, and ceased to purr, but Julia sent to Mr. Bergh's office for a dog-doctor, and the dog-doctor cured the cat.

I believe that $\mathrm{Mr}$. Hayes in spite of your fears, will make a good President. I think, from what I hear from Washington, and especially from what is told me in a letter which I received this day from Mr. Briggs, ${ }^{2}$ who is there, that he means to settle the quarrel in the southern states in the right way. He is not so able a man, as Tilden, nor is it possible that he can be so enlightened in certain respects, having a different and inferior political training, but I think him conscientious, and he has the credit, among those who know him best, of being firm, not to say obstinate, in his resolutions. It may be true, as you say, that Mr. Tilden's cause was prejudiced at the South by the assertion of his firm determination to resist the payment of the rebel war claims. I know however, that the danger of the payment of those claims, if the democrats should obtain the power, was used with great effect against Mr. Tilden here. But I do not think, and I never thought, that there was, or will be, any serious danger of those claims being paid, let who will be President.

We have had on the whole a pleasant winter and till lately a healthy one. The month of February was sunny and mild with dry streets, and March came in like May to go out, as it is now going out, in a storm lasting three days-a cold rain on Monday and Tuesday and today a long snow storm ending in cold high winds from the northwest which have been blowing all day.

I am sorry to learn that Harriet ${ }^{3}$ continues in a bad state of health, and that the little boy suffers. Please give my regards to all the family.

Julia sends love to all-

Yours affectionately, W. C. BRYANT. 
MANUSCRIPT: NYPL-BFP ADDRESS: Jn ${ }^{\circ} \mathrm{H}$. Bryant Esq.

1. Such a chapter seems not to have been included in the Popular History.

2. Probably journalist Charles F. Briggs. See 915.1. Briggs' letter is unrecovered.

3. John's wife.

2473. To Charles Dennis, Jr. ${ }^{1}$

Dear Sir

Roslyn Long Island N.Y. April 10th. 1877.

I do not find any fault with the phrase "Tomorrow is Monday." It is a phrase often used by those who speak the language most correctly and good usage makes a language. Tomorrow is-what? The answer is Monday. It is Monday now, it will be Monday tomorrow and will remain so ever afterward-only it will not be tomorrow.

Yours respectfully

W C BRYANT

MANUSCRIPT: Joseph G. Astman ADdRess: Mr. Charles Dennis jr.

1. Unidentified.

2474. To J. M. W. Geist ${ }^{1}$

New York, April 24, 1877.

\section{Dear Sir:}

The name of your journal is one of good omen. I really hope that we are entering upon a new era.

Not that I suppose that every wrong in the political world will be thoroughly reformed, and that hereafter everything that is done will be done wisely and with worthy motives. But I see that the attention of the people is turned towards reform. They have become impatient of corruption in office, of negligence and incompetency in places of public trust, and are determined to put the best men in office and hold them to a strict accountability.

In that earnest determination your journal, as I understand its purpose, will zealously co-operate. We look to it, and such other journals as are established with a like purpose, for effectual aid in this important work.

May the issue of your journal mark the beginning of this new order of things.

Yours truly,

W. C. BRYANT 
MANUSCRIPT: Unrecovered TEXT: New Era, Lancaster, Pennsylvania, of uncertain date.

1. Former editor of the Lancaster Examiner and Express, who had apparently solicited Bryant's endorsement of a new Republican paper, The New Era.

2475. To Hamilton Fish

Dear Sir.

The Evening Post, Broadway and Fulton Street New York, April 281877.

The arrangements for Unveiling the Halleck statue are in such a state that a final meeting of the Committee for Consultation is thought necessary. ${ }^{1}$ Can you spare time to come to the office of the Evening Post on Monday the 30 th instant for a few minutes?

Yours truly

W C BRYANT

Chairman \&c.

MANUSCRIPT: LC ADDREsS: Hon. Hamilton Fish.

1. Bryant presided over the dedication of this statue of Fitz-Greene Halleck on the Mall in Central Park on May 15, 1877. See 2161.4.

2476. To Julia S. Bryant

Dear Julia

Roslyn, L. I. May 1st 1877.

Everything here is beautiful-high grass of the lushest green the forsythia and Japan quince in full bloom and several of the spiræasthe trees putting out their leaves half grown-and several kinds of garden flowers already unfolded not to mention the almond and peach trees in bloom and one cherry tree. If you were here you would not want to go back again. Mr. Cline thinks that Jerry ${ }^{1}$ could not have looked at our place-

Yours affectionately

W. C. BRYANT

MANUSCRIPT: NYPL-GR ADDRESS: Miss Julia Bryant.

1. Apparently the Bryants' coachman.

2477. To John T. Johnston

My dear sir.

New York May 1st. 1877.

I have your letter of the 27 th of this month. I wrote the letter and the order to which you refer after a conversation with Dr. Osgood in 
which I probably misunderstood him. I see now that the Bryant Vase was intended by the donors to be placed in the Museum of Art as a permanent deposit-and I see that this would be the wiser course. I send another order, enclosed. ${ }^{1}$

Yours faithfully

W. C. BRYANT.

MANUSCRIPT: MMA ADdREss: To John Taylor Johnston Esqre. DOCKETED: 1877 New York May 1st / W. C. Bryant / Rec. May $2^{\text {nd. }}$

1. See Letter 2459. Johnston's letter is unrecovered, as is Bryant's order.

2478. To James G. Wilson

New York, $c$ May 1, 1877.

.. . I have just received the accompanying letter ${ }^{1}$ from the Park Commission. It seems that somebody must confer with $\mathrm{Mr}$. Olmsted and the Superintendent. ${ }^{2}$ I have no time to do it and as you have had the whole matter on your shoulders, I empower you so far as I am concerned to see those gentlemen and act with full power. . . ${ }^{3}$

MANUSCRIPT: Unrecovered TEXT (partial): The Collector, of unspecified date.

1. Unrecovered.

2. Frederick Law Olmsted, no longer superintendent of Central Park, was the head of the Bureau of Design and Superintendence in the New York City Department of Parks.

3. Bryant was chairman of the committee for the erection of the Halleck statue; Wilson, Halleck's biographer, had been chiefly instrumental in raising funds for the purpose.

2479. To Florence Wolf ${ }^{1}$

Dear Madam.

The Evening Post, Broadway and Fulton Street. New York, May 4th 1877

I have your letter ${ }^{2}$ and have read the accompanying verses. They are not-so at least it seems to me, who do not profess to be a criticsuitable for publication on account of what you rightly name, a certain "crudeness," and an inadequacy in the expression of the thoughts. Language is a machine which requires great skill in the conveyance of poetic emotion and imagery. You will yet if you continue to write greatly surpass what you have yet done. 
MANUSCRIPT: UVa ADDRESS: Miss Florence Wolf / Care of the Hon. Simon Wolf /

Washington / District of Columbia. POSTMARK: NEW YORK / MAY 4 / 130 PM.

1. Apparently a daughter or sister of Simon Wolf (1836-1923), German-born Washington lawyer and judge.

2. Unrecovered.

2480. To Sydney H. Gay

Dear Mr. Gay.

New York May 5, 1877.

I have read the first chapter of the second volume of the History with great interest. It is capitally done. I have noted one or two little things.

Page 3 just below the engraving. I would strike out the words "the helmet" in brackets-the sense is clear without them.

Page 6 "dreaded war whoop" seems to imply that the war whoop was already sounding in the ears of the worshippers while the preaching was going on.

near the middle_- "under Underhill" has a bad sound-led by Underhill would be better. ${ }^{1}$

Pages $19+20-$ You state the reasons why the Indians were so slowly converted to Christianity-Was not forgiveness of injuries-the Christian doctrine of rendering good for evil-so utterly at variance with the Indian morality one reason and a very powerful one?

Suggestions \&c.

At the places on which I have remarks to make I have put this mark, with a lead pencil in the margin.

Page 46 "region of country" leave out the words "of country."

"go to pieces" would not "revert to anarchy", or some such phrase express the meaning better.

" 47 is not the word "we" omitted here before "do?"

" 48 "common compact for mutual protection" the word "common" is it necessary?

" 55 "erotic offenses" say "offenses of this kind."

" 60 "pronounced" here is a genuine Gallicism-Is not "complete" or "perfect" better?

"escaped domination into Connecticut" is not "from" required before "domination"

" 61 "sombre presence"-gloomy? austere?

at the top of the page "incomprehensible distinction"-not quite exact-not incomprehensible-but "subtle" "subtlydrawn." I think I might understand them. 
" 63 "the attempt to suppress it" for it, read "its exercise"

" 64 The sentence beginning "Indeed the wonder is" \&c. A fact is intimated here which I think ought to be stated directly namely that the Cambridge Synod ${ }^{2}$ had made up a list of eighty two heresies from a certain controversy- Writing history by allusion is unsatisfactory- In the sentence preceding this certain "vagaries of thought" are said to be "incomprehensible to those who cherish them"- Is that true? I think they attached to them a distinct meaning.

Page 68 "cantankerous and unpliable" I object to both words-the first is burlesque, not to say slang-the second is a word more appropriate to substances than to moral qualitiesWhy not pragmatical or contentious and unyielding? Unpliant is better than unpliable.

P.S. I send a book which I have received

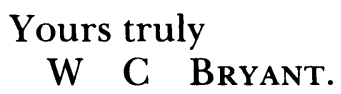

W.C.B.

MANUSCRIPT: CU ADDRESS: S. H. Gay Esq.

1. John Underhill (c1597-1672), a Connecticut captain in the war against the Pequot Indians in 1637.

2. A ruling church body in the early Massachusetts Bay Colony.

2481. To Frederick Law Olmsted ${ }^{1}$

Dear Mr. Olmsted

New York May 16th 1877.

I was satisfied with the assurance which you gave me, yesterday, that every thing was done that could be done to see the ladies and others comfortably established in their seats around the platform in the Park. The occasion ${ }^{2}$ was of such a nature-the presence of the President having attracted such an immense crowd moved by an irrepressible curiosity-that nothing but a very large force of police could have restrained the multitude from pressing inconveniently upon the ladies after they were seated.

Yours truly, W. C. Bryant.

MANUSCRIPT: LC ADDRESS: F. L. Olmsted Esq.

1. This is the only recovered letter from Bryant to the designer and superintendent of Central Park during their long friendship and professional association.

2. The dedication of the Halleck statue. See Letters 2475, 2478. 
2482. To Julia S. Bryant

Dear Julia

Please look for the keys to my trunk-two keys tied with bright red tape and send them out to me tonight-Saturday- I made two blunders - The letter to Mr. Cline I found in my pocket.

Affectionately

W C BRYANT

MANUSCRIPT: BLR AdDREss: Miss Julia Bryant / No. 24 West 16th Street / New York. / Will Mr. King please send this to / Miss Bryant for some keys and wait for an answer.

2483. To A. Hamilton Mulligan ${ }^{1}$

\section{Dear Sir}

New York. May 21 st 1877.

I find that I cannot attend the interesting Memorial Services to be held in the Academy of Music on the 30th. instant, ${ }^{2}$ and must content myself with thanking the Executive Committee for their politeness in adding my name to their list of invitations.

$$
\begin{aligned}
& \text { I am, sir, } \\
& \text { very truly yours. } \\
& \text { W. C. BRYANT. }
\end{aligned}
$$

ManusCript: Andrew B. Myers Address: A. Hamilton Mulligan Esq. / Secretary of the Executive / Committee.

1. Not further identified.

2. The occasion for this ceremony is uncertain.

2484. To [Whomsoever it may concern $]^{1}$

Mrs. Laura S. Webb, is a lady among whose good qualities of character are a warm love of country, and an uncommon energy, and who is well and favorably known to the public as the author of "A Prayer for Peace" and "Custer's Immortality," to which might be added the poem of "Liberty enlightening the World," of which I think, only part has been published. ${ }^{2}$ She is also well known throughout the South and west, as editor of the "Western Sun," a newspaper first published at St. Louis, but afterwards transferred to New York, before the panic of 1873 broke out, and caused its suspension. It is now to be revived by its persevering and enterprising editor, under the suggestive name of 
"The Patriot."

As its name indicates, it is Mrs. Webb's intention to conduct this journal in conformity with the principles of American Patriotism. As she is already widely known throughout the Southern and Western states, her journal promises to be an excellent advertising medium for those eastern merchants who wish to secure the western and southern trade. I have only to add my sincere wish, that this deserving lady who has laboured with so laudable a zeal for the reconciliation of the North and South, may find her reward in the prosperity of her new enterprize.

[William Cullen Bryant] ${ }^{3}$

MANUSCRIPT: University of Rochester Library DOCKETED: Wm Cullen Bryant / N. York 1877.

1. Lettered in unidentified hand.

2. See Letter 2413.

3. Inserted, as in Note 1 above.

2485. To Edward A. Oldham ${ }^{1}$

Roslyn, Long Island N.Y. May 26th. 1877.

Dear Sir.

If Mr. Thompson's poems had been published in his life time I think that they would have been readily sold, inasmuch as he was well known, more particularly at the south as an accomplished man of letters. ${ }^{2}$ I think the time which has elapsed since his death has made some difference-new names having occupied the public attention, so that I think there would be some doubt of a large sale. Still, I remember that as a writer he was regarded at the south with great favor and had many personal friends in that quarter. I wish I could answer with more confidence. I can only simply say that I think the success of an edition of his poems doubtful - not by any means certain to repay the expense, with a moderate profit-and yet, possibly, so far successful.

Yours faithfully

W C BRYANT

MANUSCRIPT: Andrew B. Myers AdDREss: Edw ${ }^{d}$ A. Oldham Esq.

1. Unidentified.

2. John R. Thompson, late literary editor of the EP; see 1951.3. 
2486. To John T. Johnston

My dear Sir.

Roslyn, Long Island N.Y. May 28th. 1877.

The work of art called the Bryant Vase, presented to me by my friends as a token of their good will being now in the Rooms of the Metropolitan Museum of Art, I write this by way of carrying into effect the intentions of the donors. I wish it to be understood, that I have placed the Vase in the Museum, that it may remain in charge of its officers, a permanent and perpetual deposit, among the objects of art which form the collections of the institution.

$$
\begin{aligned}
& \text { I am, Sir, } \\
& \text { faithfully yours, } \\
& \text { W. C. BRYANT }
\end{aligned}
$$

MANUSCRIPT: MMA AdDress: To John Taylor Johnston Esqre. / President of the Metropolitan Museum of / Art.

2487. To Jerusha Dewey

Roslyn, June 2, 1877

... I stop in the midst of reading Miss Martineau's memoir of her own life-an entertaining book for the most part, with one or two tedious places; but how immensely conceited the woman was! ${ }^{1}$ One would think, on reading what she says of herself, that the whole world stood still while it was waiting for her directions. She is very contemptuous in her judgments of almost every eminent person whom she had any acquaintance with, and expresses her contempt without the least reserve. I perceived that trait in her character when she was here. She seemed to fancy that she had crossed the Atlantic to enlighten us in regard to our duty and interest, and that all we had to do was to submit ourselves to her guidance. Her notions in regard to another life are amusing. It makes no difference, according to her, whether it is we who live after we die or somebody else. It is mere selfishness to wish for an existence beyond the grave, when it is plain that if somebody else is alive after we are buried it is just as well. The world will go on after we have left it; other people will live, and that is as good as a resurrection.

I have read every word of Canon Kingsley's "Life and Letters," and thought better of him for reading it. He was very decided in his opinions, but very modest in his notion of his own merits; and, though conservative in regard to the Anglican Church, tolerant and kind to those who did not agree with him. He was a friend to the humbler 
classes, and a most faithful and sympathetic pastor, wearing out his life for his flock; yet I cannot see that he contemplated doing them any good, save by personal effort and kind attentions. I do not find in any part of the memoir that he sought to improve the institutions under which the working class in England had been kept poor and degraded. But his personal attentions with respect to their comfort, their health, their spiritual condition, and their mental improvement, were constant, and these, along with his literary labors, undermined his health and broke it down once in two or three years. He was a worn-out man when he came to America. ${ }^{3}$ But read the book, if you can get it. If you skip anything, skip the letters in which he tries to be jocular and runs into slang-mere slang, which he seems to take for fun....

MANUSCRIPT: Unrecovered TEXT (partial): Life, II, 382-383.

1. Harriet Martineau, Autobiographical Memoir, published after the author's death in 1876. Bryant had met Miss Martineau on several occasions, both in the United States and in England; see 313.5 and Letter 546.

2. Charles Kingsley (1819-1875): His Letters and Memories of His Life. Edited by His Wife (London, 1877).

3. Kingsley had visited the United States in 1874.

2488. To George Stewart, Jr. ${ }^{1}$

\section{Dear Sir.}

Roslyn, Long Island N.Y. June 4th. 1877.

I have your note with the periodical containing what you have said of the literary merits of Dr. [Oliver Wendell] Holmes. ${ }^{2}$ You have not commended him beyond his deserts. For my part it seems to me that in the way of playful and at the same time graceful humor we have scarce any thing so fine in English since Addison.

As to the inquiries you make concerning myself I can tell you scarce any thing that seems likely to interest the public. ${ }^{3}$ You will find most of the principal incidents of my literary life related in Allibone's Dictionary of Authors and in Duyckinck's Cyclopedia of American Literature.

I began to write verses early, composing them at eight or nine years of age. At thirteen I published a pamphlet in verse of which a second edition came out the next year. I wrote the poem entitled Thanatopsis, all but the introductory lines and the conclusion, in my eighteenth year. The poem entitled "To a Waterfowl" was written in my twenty first year. It was suggested by seeing a waterfowl flying northward in a sky crimson with the falling sun. I was then a student 
at law about to be admitted to the bar and quite uncertain where I should fix my abode. ${ }^{4}$ It was first printed in the North American Review in 1818. The poem entitled Green River was written somewhere about 1820, and in 1821, published in Richard H. Dana's "Idleman," when I lived near the Green River in Great Barrington Massachusetts. While there I wrote between 1816 and 1825 the Forest Hymn and more than twenty other poems which appeared in the Boston Literary Gazette, a periodical issued twice a month. I went to New York in 1825 and was immediately concerned in editing the New York Review for which I wrote the "Song of Pitcairn's Island," "The Skies," "The Hymn to Death," "The Death of the Flowers," "To the new Moon," and one or two others. The New York Review in 1826 and 1827, being united with another periodical became the United States Review and I wrote for it "The Damsel of Peru" "The African Chief" "Spring in Town" and several other poems. In New York I took some pains to acquire the Spanish language, and several of the poems contributed were translated from the Spanish. "The Future Life" "The Life that Is," and "October 1866" are poems addressed to the same person-the latter after her death. The poems entitled "Sella," and "The Little People of the Snow," with many others were not written for any periodical but composed as I was moved to write by the impulse of the moment and kept by me in manuscript for some time. In 1865 I began to translate the Iliad of Homer and finished the work together with my translation of the Odyssey in December 1871. The last edition of my poems contains "The Flood of Years." [It] was written nearly a year since. The thought had been for some time in my mind, and at last I took it up and made a poem of it.

$$
\begin{aligned}
& \text { I am, sir, } \\
& \text { very faithfully yours. } \\
& \text { W C BRYANT. }
\end{aligned}
$$

MANUSCRIPT: Toronto Public Library ADDREss: George Stewart jr. Esq.

1. Identified only as in Note 3 below.

2. This periodical is unidentified. Stewart's note is unrecovered.

3. Stewart, apparently a Canadian, incorporated this information in a chapter on Bryant in his Evenings in the Library: Bits of Gossip About Books and Those Who Wrote Them (Saint John, New Brunswick, 1878), pp. 161-193.

4. Modern studies suggest that, while Bryant's account of the composition of "To a Waterfowl" is substantially right, the date he assigns to "Thanatopsis" is probably several years too early. See William Cullen Bryant II, "The Waterfowl in Retrospect," New England Quarterly, 30 (June 1957), 181-189; "The Genesis of 'Thanatopsis,' " ibid., 21 (June 1948), 163-184. 
2489. To Victor H. Huff ${ }^{1}$

Dear Sir.

Roslyn L.I. June 5, 1877.

The true reading of the lines to which you refer is-

The mountain shudders \&cc

and-

The clouds before you shoot like eagles $\& c^{2}$

Yours respectfully

WM C BRYANT

MANUSCRIPT: HCL ADDRESS: Mr. Victor H Huff.

1. Unidentified.

2. Quotations unidentified.

2490. To Henry A. Lavely ${ }^{1}$

Dear Sir.

Roslyn, Long Island N.Y. June 6, 1877

I leave the business of making arrangements for the publication of the History of the United States with Messrs Scribner Armstrong \& Co of New York, being myself only one of several partners in the undertaking. I have sent your letter ${ }^{2}$ to them, that they may answer you- There is but one volume out, another is passing through the press and there are to be four.

$$
\begin{aligned}
& \text { I am sir } \\
& \text { respectfully yours } \\
& \text { W C BRYANT. }
\end{aligned}
$$

MANUSCRIPT: CHS ADDRESS: Henry A. Lavely Esq.

1. Unidentified.

2. Unrecovered.

2491. To John Howard Bryant

Dear Brother.

Roslyn, Long Island N.Y. June 14th 1877.

I hope you are thinking of making your annual summer visit to Cummington. I want you to see how matters are going on under the new arrangement with Smith and Dawes. I hear that the potato beetle has made his appearance there and that Smith is [salting?] them with 
Paris Green, while Tower refrains from using that method out of regard to my prejudices and is fighting the pest with main force. I have sent word to Mr. Trow that he can, if he pleases drain the beaver dam for the sum he offered to do it for-fifty dollars.

If you come to Cummington you will come on the same conditions as last year-that is to say that you are to pay your expenses out of the money which you have of mine in your hands.

I wish you were here at this moment to try our strawberries which are very large this year and so abundant that we hardly know what to do with them. Mr. Cline is laboring hard to keep even with them, gathering them as fast as they ripen and sending them about to the neighbors, none of whom seem to have any thing like them. I have discovered also how to have more raspberries than I want in this gravelly soil-namely, by mulching them very deep. It makes the canes grow enormously, and they are covered with clusters of berries.

I saw Ebenezer Snell of San José ${ }^{1}$ last March. He called upon me in Sixteenth Street, but I could not keep him over night. He had been to see the old place in Cummington and seemed interested and pleased with the changes. He is still more pleased with his own

and dwelt upon ${ }^{2}$

Our summer here has been pleasant so far with the exception of a few hot days in May. The fruit here is promising well; the hay will be but a moderate crop, the potato bug is not likely, they say, to do the mischief which was done last year and the Indian corn is coming forward finely. Mr. Cline says he hopes to see you at Cummington, inasmuch as he expects to be there when we go, as was the habit with him before his accident. He is getting on although very slowly-lance still in hand and foot, but both growing more serviceable.

I will write and let you know, to a day, when we are planning to be in Cummington. Julia desires her love to all. Mine to all your household. Harriet I hope will feel the influences of this genial season and improve in health. ... ${ }^{3}$

MANUSCRIPT: WCL ADDRESS: Jn ${ }^{\circ} \mathrm{H}$. Bryant Esq. 1857).

1. Apparently Cullen's first cousin, a son of his uncle Ebenezer Snell, Jr. (1771-

2. A gap in the text here resulted from the cutting of Bryant's conclusion and signature.

3. Conclusion and signature clipped.

2492. To Rutherford B. Hayes

Sir.

Office of the Evening Post

New York, June 22d 1877.

I write in behalf of Mr. Joseph B. Wiswall, of this city. ${ }^{1} \mathrm{He}$ desires an appointment to a consulship in some foreign port, or some other 
port which requires equal qualifications. He is a gentleman of excellent reputation, well educated and well-informed, and possessing a decided capacity for business. On all these accounts, he is held in high esteem by the merchants and men of business in this city. His appointment would be creditable and satisfactory both at first and in the end. ${ }^{2}$ I enclose two or three testimonials to his merit.

I am, sir, with great regard yours. W. C. BRYANT

MANUSCRIPT: RBHL ADDRESS: To President Rutherford B. Hayes.

1. Probably a relative of John Bryant's wife Harriet (Wiswall) Bryant. See Volume I, 12.

2. That Bryant persisted in his effort to help Wiswall is evident from a letter to Bryant from Theodore Roosevelt the elder (1831-1878) dated October 24, 1877 (NYPL-BG). Here the father of the future president promised that if he were appointed Collector of Customs for the Port of New York he would consider employing Wiswall. But Roosevelt failed of ratification by the senate because of the enmity of Senator Roscoe Conkling (1829-1888) of New York, a bitter opponent of President Hayes. Edmund Morris, The Rise of Theodore Roosevelt (New York: Ballantine, 1979), pp. 93-94.

2493. To Anna $Q$. Waterston

Roslyn, June 25th [1877]

. . . A letter, addressed by you to Mrs. Spring, having been sent to me for my perusal, has reminded me that I have neglected to write to you by way of expressing my sympathy with you and my good friend, $\mathrm{Mr}$. Waterston, in the great loss you have sustained by the death of your brother, Edmund Quincy. ${ }^{1}$

The circumstance which forms the principal consolation under this loss-namely, the blameless and beneficent life of your brotherserves only to heighten the calamity. There is yet another, though not an equal, consolation, in the universal acknowledgment of his worth. When a good man departs it is fortunate for mankind if he leaves behind him a memory which the world holds in reverence, and to which men refer as embalming an example worthy of universal imitation. It is thus that he may be said to live after death-not merely in the spiritual world to which he has passed, but in the minds of those who are encouraged to emulate his goodness by the testimonies of affection and sorrow which they who best knew him bring to his grave. In this way his agency in doing good survives the term of his existence on earth. ...

MANUSCRIPT: Unrecovered TEXT (partial): Life, II, 383-384.

1. Edmund Quincy (1808-1877, Harvard 1827), a radical reformer and leading Abolitionist. 
2494. To Mary W. Tileston ${ }^{1}$

Dear Madam.

Roslyn, Long Island N Y. June 26th. 1877.

Certainly, you are welcome to take the poems you mention, for your collection, ${ }^{2}$ and if there be any other that I have written which suits your purpose, you are welcome to include that also.

Yours respectfully

WM. C. BRYANT

MANUSCRIPT: Kent State University Library ADDREss: Mrs. Mary W. Tileston.

1. Mary Wilder Tileston (1843-1934).

2. In 1874 Mrs. Tileston had published at Boston Quiet Hours: A Collection of Poems. No copy of this has been found. Perhaps she was planning a new edition of this work.

2495. To Joseph Neilson ${ }^{1}$

My dear sir.

Roslyn, Long Island N.Y. June 301877.

I am glad to learn that you are engaged in writing the Life of that eminent advocate, the late Mr. Choate. ${ }^{2}$ The lives of distinguished lawyers and great orators are peculiarly interesting, and in the subject of your memoir, you will have a most remarkable man of that class, endowed with the gift of persuasion-such as few possessed.

I am, sir, faithfully yours. W. C. BRYANT.

MANUSCRIPT: NYPL-GR (draft) ADDRESS: To the Hon Joseph Neilson.

1. Joseph Neilson (1813-1888).

2. Rufus Choate (1799-1859, Dartmouth 1819), United States senator from Massachusetts, 1841-1845, and an associate of Daniel Webster in Whig councils, had been pre-eminent as a courtroom advocate. Neilson's work was Memories of Rufus Choate, With Some Consideration of His Studies, Methods and Opinions, and of His Style as a Speaker and Writer (Boston and New York, 1884).

2496. To John Howard Bryant

Roslyn L.I. N.Y. July $2 \mathrm{~d}$ 1877 .

Dear Brother.

I have a letter from Charles H. Bryant asking me to lend him a thousand dollars taking for security his place at San José, the title to 
which is good, and on which he now owes five hundred dollars-the only debt he owes. ${ }^{1}$ He will pay ten per cent interest, and wants the loan for two years. His law business he says is increasing, though there is much competition; his place he tells me will sell for $\$ 2500$-and if he gets the loan he will pay off the debt immediately and leave the place clear for securing the loan from me.

$\mathrm{He}$ is a deserving young man and I should be glad to oblige him, but I cannot spare the money yet from here-though the revenues of the Evening Post are somewhat improved since the dividend in November last. Please to consider this matter carefully and write to Charles as soon as may be convenient. I cannot afford to give the amount to him, as things look now, but I am desirous to accommodate him. It may be that you have not the money to send him when you receive this, but expect it soon- In that case you will let him know how it is, and perhaps he will prefer to wait for it. I leave the matter in your hands, with this remark, that perhaps seven per cent would be all that I ought to require of him-that being what I have received of other relatives to whom I have lent money. The interest he says he will pay quarterly or annually as I please.

I have your letter relating to your visit to Cummington, which I hope you will be able to make. I am sorry to learn concerning Julia Olds that her health is so bad. ${ }^{2}$ I hope that she has found the farm of some use to her though. I have not heard whether she keeps the land or not. If you write in answer to this I wish you would tell me.

We have had delightful weather here of late, varied with refreshing showers which keep the fields in a fresh verdure. The crops look well-my wheat and rye are heavy and the oats promise well, but the potato is visited by its old enemy, the Colorado beetle, ${ }^{3}$ and we are fighting it and waiting for its destroyer, the insect which has delivered the western States from its ravages. We have had as fine strawberries as were ever ripened by the sun and they are on the point of going out after a calendar month's duration.

I hear from Mr. Tower that things are going on well in Cummington, but he has had a severe battle with the Colorado pest. The winter was uncommonly snowy and broke down many young trees with snow and ice.

I hope to hear that Harriet is better. Give her and the others of your household my kind regards.

Yours affectionately

W. C. BRYANT

MANUSCRIPT: NYPL-BFP ADDRESS: Jno. H. Bryant Esqre.

1. Austin Bryant's third son, Charles Howard Bryant (1832-1879). His letter is unrecovered. 
2. Julia Louisa Olds (1840-1891?) was the second daughter of Bryant's sister Charity Bryant Olds.

3. The Colorado potato beetle, or common potato bug.

2497. To the Editor, Christian INTElligencer

Roslyn, July 6th, [1877] ${ }^{1}$

... It seems to me that in style we ought first, and above all things, to aim at clearness of expression. An obscure style is, of course, a bad style. In writing we should always consider not only whether we have expressed the thought in a manner which meets our own comprehension, but whether it will be understood by readers in general.

The quality of style next in importance is attractiveness. It should invite and agreeably detain the reader. To acquire such a style, I know of no other way than to contemplate good models and consider the observations of able critics. The Latin and Greek classics of which you speak are certainly important helps in forming a taste in respect to style, but to attain a good English style something more is necessarythe diligent study of good English authors. I would recur for this purpose to the elder worthies of our literature-to such writers as Jeremy Taylor, and Barrow, and Thomas Fuller²-whose works are perfect treasures of the riches of our language. Many modern writers have great excellences of style, but few are without some deficiency.... .

I have but one more counsel to give in regard to the formation of a style in composition, and that is, to read the poets-the nobler and grander ones of our language. In this way warmth and energy are communicated to the diction, and a musical flow to the sentences. . . .

MANUSCRIPT: Unrecovered TEXT (partial): Life, II, 384-385, excerpted from full text in Christian Intelligencer for July 11, 1877.

1. Mistakenly dated 1863 in Life, II, 384. No copy of the letter's original publication has been located.

2. Taylor (1613-1667, Cambridge M.A. 1634), Anglican bishop and widely read writer on religious subjects; Isaac Barrow (1630-1677, Cambridge B.A. 1649, M.A. 1652), a theologian who wrote in a highly skilful prose style; Thomas Fuller (16081661, Cambridge M.A. 1628), now best remembered for his incomplete History of the Worthies of England (1662).

2498. To J. C. Derby

Dear Mr. Derby.

cJuly 7, 1877.

I send you a manuscript copy of my letter to Mr. Richards. ${ }^{1}$ I thought I had several of them in print but can find only one which I want to keep. 
As to your own habits of life, I would observe that it is never too late to begin a good course. [Cimaro?] who lived to almost a hundred years began to live rationally when he was over forty and was thought to have ruined his constitution by his disorderly habits, but recovered and was strong and cheerful. But it is not necessary that you should take so much time in your exercise as I do-half the time would answer for you. ${ }^{2} \ldots$

MANUSCRIPT: NYPL-GR (draft).

1. Letter 1986, to Joseph H. Richards.

2. Derby had written Bryant on July 7 asking for an autographed copy of that letter for publication in the Popular Science Monthly, and enquiring whether it might be too late for him, nearing the age of sixty after an inactive life, to begin the strenuous exercises which Bryant described in the letter as his own morning regimen. NYPL-GR.

2499. To Stephen C. Massett ${ }^{1}$

Dear Mr Massett.

Roslyn, Long Island N.Y. July 9 th 1877.

You sent me some time since a poem by Miss Pittsinger ${ }^{2}$ and asked me what I thought of it. It happened that I laid it in a book that I was reading and the book having been laid aside I could not find it again until now.

The verses are very creditable to the lady. They show a poetic mind and much facility in versification, and if the writer cultivates her talent she may produce still better things. Perhaps the thought is sometimes a little obscured by the luxuriance of the expression but this is a pardonable defect in a beginner.

$$
\begin{aligned}
& \text { Yours truly } \\
& \text { W C BRYANT. }
\end{aligned}
$$

MANUSCRIPT: Andrew B. Myers ADdREss: Stephen Massett Esq.

1. See 1420.1 .

2. Unidentified. The poem is unrecovered.

2500. To Jerusha Dewey

Dear Miss Dewey.

Roslyn, Long Island July 12th 1877 .

Certainly, you shall come to us whenever you please, if not in August or September at Cummington, then in the month of October 
at Roslyn. You seem to have put some obstructions in your way at present; I should be glad if they could be easily removed, but if they cannot we must yield to circumstances.

You ask whether Jere Black is an authority in political matters. ${ }^{1} \mathrm{I}$ think it would make those who know him smile to know that you had asked the question. He is a vehement partisan and nothing else when politics are concerned-though he is a lawyer-an advocate of some note, and I suppose large practice. I began to read his article in the North American Review, but did not like the tone of it, seeing that he began to call names before he had brought forward his proofs and arguments. $^{2}$

I suppose for my part that there is no knowing on which side the cheating was the greatest. If there had been a perfectly fair election at the South with no intimidation and no improper influences brought to bear upon the blacks in the Southern states the strong probability is-I think - that Hayes would have had the constitutional majority. But there was intimidation-a great deal of it-perhaps of a sort for which there was no remedy, such for example as is practised here at the north by owners of manufacturing establishments and other employments-influences of which the law cannot take notice. The returns from the different districts of the Southern states would, therefore, if not tampered with in any way after they had been formally made out, have in all probability secured the election of Tilden-but, even then, would have left the doubt whether he was fairly elected. To counteract the effect of what was done by the whites working on the interests and fears of the blacks the scheme of having Returning Boards was invented. They were managed by Republicans and threw out all the returns which they took a fancy to say were from districts in which intimidation was practised. It is likely that they threw out some returns which they ought not-but at all events they threw out enough to elect Hayes if their doings were approved. If it had happened that the Electoral Commission in their verdict had set aside the proceedings of the Returning Boards which had been legalized by the legislatures of the Southern States and declared that Tilden was elected it is not all improbable that the Republicans would have complained of fraud and conspiracy and injustice as the Democrats now do. So, you see, each party has a plausible case.- Excuse the blot below. You see Mr Knapp and his family occasionally I suppose. Please present my regards to them.

\author{
Yours very kindly \\ and truly W. C. BRYANT
}

MANUSCRIPT: NYHS ADDRESS: Miss J. Dewey PUBLISHEd (in part): Life, II, 385-386.

1. Jeremiah Sullivan Black (1810-1883) was a Pennsylvania lawyer and judge who had been Attorney General, and briefly Secretary of State in the Democratic 
administration of President Buchanan, and represented Tilden before the Electoral Commission, which decided in favor of Hayes in the 1876 election.

2. This article has not been identified.

2501. To Christiana Gibson

Roslyn, July 12th [1877].

... I went on the 26th of June to Easton, in Pennsylvania, and was present at the Commencement of Lafayette College. I was sent for, of course, and was piloted by Dr. Alden, the head of the Normal School at Albany. The occasion was, that among the prizes given out to the young men there was one called "the Fowler prize," which is given every year to the author of the best essay on the life and writings of some English author-that is, an author writing in the English language-whom the Faculty designates for that purpose. This year I and my writings were the subject, and the prize was an elegantly bound copy of my works, in eight volumes. I was called upon to present them, in the name of the college, to the winner of the prize, which I did with an apology for their want of merit. ${ }^{1}$ The essay I did not see, nor ask to see, but it was probably better than the subject. I wish you could have been at Easton to see the president of the college, Dr. Cattell ${ }^{2}$-jolliest and gayest of all principals of such institutions, always jesting and smiling, fondling the students, as he does his children, and yet not losing their respect nor missing their obedience. The institution is quite popular. Last year it had three hundred and thirty-two students; the number of professors and other teachers is twenty-eight. ...

MANUSCRIPT: Unrecovered TEXT (partial): Life, II, 386.

1. After a salutatory tribute to him in Latin, Bryant awarded the prize to James Wilson Bright (1852-1926, Lafayette 1877), later (1893-1925) a distinguished philologist at Johns Hopkins, and from 1896 to 1925 editor of Modern Language Notes. In his remarks Bryant recalled his visit to Easton in 1846 (Letter 604) and remarked on the beautification of the college campus since that time. Lafayette College Journal (July 1877), pp. 325-328; David Bishop Skillman, The Biography of a College (1932), pp. 391393.

2. William Cassaday Cattell (1827-1898), Presbyterian clergyman and president of Lafayette College (1863-1883).

2502. To John T. Seymour ${ }^{1}$

Dear Sir.

Roslyn, Long Island N.Y. July 12th. 1877 .

For various reasons I cannot attend the commemoration of the Battle of Oriskany, to which your Committee has obligingly invited 
me. ${ }^{2}$ I owe you many thanks for the kind terms with which you have accompanied the invitation, and which, were I a younger man, might have persuaded me to leave this retreat. As to the ode, of which you speak, I have already declined two requests of the kind, and one I have complied with, solely because I incautiously said something which was understood as a promise. ${ }^{3}$ But it is too late for me to think of writing verses for public occasions. If I were to employ myself in such an office, I am afraid that I should appear like a gardener, who, in the beginning of winter, should attempt to raise flowers in the open air, in order to have a bouquet ready for the festivities of a New Year's Eve.

$$
\begin{aligned}
& \text { I am, sir, } \\
& \text { very truly yours. } \\
& \text { W. C. BRYANT. }
\end{aligned}
$$

MANUSCRIPT: Oneida Historical Society AdDRESS: John [F?] Seymour Esq. / Chairman of the / Invitation Committee.

1. Identified only as in descriptive note.

2. On August 6, 1777, American militiamen under General Nicholas Herkimer (1728-1777) were ambushed by a force of Indians and British Loyalists under Mohawk Chief Joseph Brant (1742-1807) at Oriskany, in what is now Oneida County, New York. Seymour's invitation is unrecovered.

3. This last was a poem he composed for the centenary of the Battle of Bennington, Vermont, won by Continental forces on August 16, 1777. See Poetical Works, II, $347-348$.

2503. To Horatio N. Powers

[Roslyn?] July 15. [1877]

... I am glad to hear anything good of General Grant and thank you for the anecdote of him given in your letter. ${ }^{1}$ His administration was, in modern phraseology, "a failure." I am willing to give him credit for any instance of good sense in perceiving his mistakes and frankness in acknowledging them, like that related in your letter. I was bitterly disappointed in General Grant, yet I see no reason to doubt his honesty. He had in the beginning of his administration, I think, some notions of what he ought to do, but they were not very clear, and the people he had about him, and who were not chosen as his associates with the sagacity which I expected, contrived to confuse them still farther, and at last he gave us an administration with all the faults of the worst which had preceded it. But his part in the history of his country is at an end, and I suppose that the merits of his military career will be hereafter more looked at than the errors of his political administration. ... 
MANUSCRIPT: Unrecovered TEXT (partial): Bigelow, Bryant, pp. 242-243.

1. Letter unrecovered.

2504. To Samuel Bowles ${ }^{1}$

Dear Sir.

Cummington, Massachusetts, August 3d. 1877.

Please add to your copy of my verses for the Bennington Commemoration the following, which has been sent to the Committee in that place. ${ }^{2}$

Yours truly

W C BRYANT

And men will hold the memory dear

Of those who fought for freedom here, And guard the heritage they won

While these green hill-sides feel the sun. ${ }^{3}$

MANUSCRIPT: Unrecovered TEXT: Holograph copy made by the late Tremaine McDowell.

1. Bowles (1826-1878) was editor from 1851 until his death of the Springfield (Massachusetts) Republican, founded in 1824 by his father, Samuel Bowles (17971851).

2. See Letter 2502.

3. On July 12 Charles M. Bliss, presumably an organizer of the Battle of Bennington centenary celebration, had written Bryant (NYPL-GR) acknowledging receipt of these verses which, he wrote, "I am sure will find a place on our monument as one of Emerson's has on the one at Concord."

2505. To Leonice M. S. Moulton

Cummington Massachusetts August 7th 1877 .

My dear Mrs Moulton.

Your note with the "magnetic pad" came to hand last night 1 -I am obliged to you for remembering me in this manner, and though I have no very great confidence in the pad as a remedy for hoarseness, or, indeed, for any thing else yet I will wear it for the sake of the prescriber. I find myself already apparently by the change of air considerably freed from the weakness and huskiness of voice which I had in Roslyn.

I am glad to learn from your letter to Julia that you are so well and strong. You would not I am sure be less so here, where the nights are cool and the days only of a genial summer warmth. A series of 
light showers have kept the fields and woods in their vernal freshness. My brother [John] and I take long walks in the neighborhood; yesterday we rambled over hill and dale, crossing the Westfield [River] and ascending the heights on the other side making in all about eight miles travel. On the top of a bare hill in a closely bitten pasture we found what we were in search of, an old deserted cemetery without any enclosure and thick with graves each with its mica slate head stone and its foot stone, all rough and uninscribed except four or five, and of these two sets recorded the life and death of two old neighbors of mine-or rather of my father and mother-in the closing years of the last century Micah White and his wife. I remember their house in Cummington; its site is now a solitary pasture on the hill-side and only its foundation stones remain, while of my former home on the opposite side of the way only a little hollow in a field marked the spot. So we go-so we pass away, most of us leaving only an old cellar as a memorial. ${ }^{2}$

I am sorry to have to say that the berry crop is small this yearthe raspberries are few and the blackberry promise scanty. There are few apples in the orchards, and though my pear trees here-young as they are produce pretty well, none of them are likely to be ripe until September or thereabout, so that I am in the midst of a dearth of fruit. I expect, however, a hamper soon from Mr. Cline.

Look, I have written you a pretty long letter, and yet have said nothing that is likely to interest you.

I hear from Miss Christiana Gibson-or rather from her sisterthat she [Christiana] ${ }^{3}$ returned from [Crete?] without any improvement of her health. At first she was better but a friend of hers, a lady, was taken ill and she bestowed so much care upon the poor lady that her own health suffered severely - Farewell, kind regards to those of your household whoever they may be now including Dr. Ordronaux. ... .

MANUSCRIPT: NYPL-Bryant-Moulton Letters.

1. Note unrecovered.

2. These sites are located and described in Only One Cummington, p. 260; see map facing p. 169.

3. These brackets are Bryant's.

4. A note added to this letter, presumably by Josephine Stewart, comments "Autograph given away."

2506. To Mary W. Tileston

Cummington, Massachusetts. August 9th. 1877.

Dear Madam

I am quite content that you should print the line "Are earnests of serener years," 
in the way that best pleases you. The alteration was made on account of a doubt whether the word "earnests" fully conveyed the intended meaning. ${ }^{1}$ But perhaps the change was not required.

\author{
Yours faithfully.
}

W. C. BRYANT.

MANUSCRIPT: Kent State University Library ADDREss: Mrs. Mary W. Tileston.

1. See Letter 2494. Bryant's reference is presumably to to a line in his hymn "Blessed Are They That Mourn": "And weary hours of woe and pain / Are promises of happier years." See Poems (1876), p. 46. But since this appears as above in each edition of his poems from that of 1832 to that of 1876 , it is unclear wherein he may have made the "alteration" to which he refers.

2507. To Calvin Durfee

My dear Dr. Durfee.

Cummington Massachusetts. August 11th, 1877.

With this note I send you the manuscript which you have asked me for. ${ }^{1}$

Yours truly

W. C Bryant.

MANUSCRIPT: WCL ADDRESS: Rev ${ }^{d}$ Dr. Calvin Durfee.

1. Perhaps this was a copy of Bryant's verses for the Battle of Bennington celebration.

2508. To Charles Parsons ${ }^{1}$

Dear Sir.

Cummington Massachusetts. August 13th 1877.

You ask for a good likeness of myself to be used in your magazine. I have no such here, nor can I give any directions to any person in New York or elsewhere which would enable him to send you one. I shall, I expect, be again in your neighborhood sometime about the end of September, if that time would answer your purpose. The photographers Sarony, Mora, and Alman have each made good photographic likenesses of me, and I have no doubt that either of them would be glad to have his engraved.

Yours truly

W. C. BRyant.

MANUSCRIPT: Lincoln College Library ADDREss: Chas. Parsons Esqre.

1. Charles Parsons (1821-1910), a British-born lithographer and marine and landscape painter, was head of Harper and Brothers art department, serving as well their two magazines, from 1863 to 1889. Eugene Exman, The House of Harper: One Hundred and Fifty Years of Publishing (New York: Harper \& Bros., [1967]), pp. 102120. 
2509. To Edward [I.?] Vose ${ }^{1}$

Dear Sir,

Cummington, Massachusetts August 17th. 1877.

A Rhyming Dictionary has already been compiled and I believe often reprinted, which answers very well the purpose of those who have occasion for such a help. Within no long time past I have seen some notice of another and newer one, said to be an improvement on the former, but I have forgotten the names, both of the compiler and the publisher. It seems to me that a new one would not be likely to succeed, but the booksellers are the best judges.

Yours respectfully

W. C. BRYANT

MANUSCRIPT: QPL ADDRESS: Edward [I?] Vose Esq.

1. Unidentified.

2510. To John H. Gourlie

Dear Mr. Gourlie

Cummington Aug. 21st 1877.

I have your letter of Saturday ${ }^{1}$ which reached me last night. It will be quite convenient for us to have you here this week, and if it should happen that you cannot come this week, then next. The country is in beautiful order, as green as in June, and will be disappointed if you do not come while she is in her finest trim. Kind regards to the ladies.

Yours very truly

W. C. BRYANT.

MANUSCRIPT: NYPL-BG ADDRESS: John H. Gourlie Esq.

1. Unrecovered.

2511. To Leonice M. S. Moulton

Dear Mrs. Moulton.

Cummington, Massachusetts. August 29th. 1877.

I have your letter before me, and must say that I commiserate you and all the inhabitants of Roslyn from the bottom of my heart. There are few things in life more vexatious than a cloud of mosquitoes about a dwelling. ...

[We have had thus] far a warmer season than is usual on these hills, and frequent showers, but not copious enough to leave little 
puddles and shallows of water simmering in the sun, from which mosquitoes are bred. The country is in its freshest green, and is very beautiful. My brother and I take long walks and climb the hills and thread the carries [portages?] and hunt up old cemeteries where the fathers of the ancient settlement of Cummington now a hundred years old were buried. But there are some drawbacks from the beauty of the season. The supply of apples, which were so fine and so abundant the two last summers is very scanty-scarce any thing in fact and the blackberry crop is a failure-you. . . . I leave Cummington so that I shall be obliged to look to your mosquito-bitten region for a supply.

We have had with us all the time till now Miss Dickson ${ }^{2}$ as Julia's companion who is a very pleasant person but she goes away in a day or two. Mr. Gourlie has just arrived for a three days visit, and has brought with him an assortment of anecdotes-things new and old. You remember that Dr. Johnson used to say that one should keep his friendships in repair ${ }^{3}$ - that is to say that one should make new friends to fill the gaps caused by the departure of the old ones. So with the pleasant story teller-he should be always adding new anecdotes to his old stock, and that Mr. Gourlie takes care to do. I remember that Rogers the poet-an admirable story teller - not in the way of mimicry, but in that of neatness of expression and the skilful selection of circumstances-repeated the same good story rather too often.

I hardly think that I shall come to Roslyn before I break up here. The insect pest of which you complain so bitterly will prevent me. Julia is not here or would ask to be kindly remembered. She is at Dalton or Pittsfield whither she went yesterday with Miss Dickson.

Yours very truly.

W. C BRYANT

MANUSCRIPT: NYPL-Bryant-Moulton Letters ADDRESS: Mrs. L. M. S. Moulton.

1. For no apparent reason, five lines on each side of this sheet have been cut from the letter. Her letter is unrecovered.

2. Probably a daughter of Dr. Samuel H. Dickson (646.3).

3. Bryant often cited this maxim; see, for instance, Letters $481,1152$.

2512. To George Haven Putnam ${ }^{1}$

My dear sir

Cummington, Massachusetts. August 30th. 1877.

What I have written on the other half of this sheet ${ }^{2}$ is, I suppose, what you require for the title of the poem you have in hand. It has seemed to me difficult to manage the embodiment, in pictures, of the images presented to the mind in the poem. I am glad to learn from 
you that the difficulty has been overcome, and shall be curious to see in what manner this has been done. ${ }^{3}$

\author{
Yours truly \\ W. C. BRYANT.
}

MANUSCRIPT: NYPL-BG AdDREss: Geo. Haven Putnam Esq.

1. The New York publisher; see 1131.3.

2. Missing.

3. This poem was doubtless The Flood of Years, published by Putnam in 1878 in an edition illustrated by William J. Linton. See Letter 2457 .

2513. To Sydney H. Gay

Dear Mr. Gay.

Cummington, Massachusetts. September 7th 1877.

I am sorry that I have not the chapter before me to which your letter of the ${ }^{1}$ instant relates. But the impression left on my mind by the narrative is that the killing of Miantonomo was without the least extenuation, when as it appeared to me, it was not at all probable that if the Puritans had been convinced of his friendly disposition, his pacific intentions and his perfect good faith, and at the same time knew the treacherous character of Uncas, they would make themselves accessories to his murder. ${ }^{2}$ In reading your account I could not help thinking - what you guard the reader against - that the Puritan authorities must, on second thought, and perhaps on further information have suspected, the good faith of Miantonomo, and weakly allowed themselves to be swayed by the suspicion, to the consent they gave to his death. I do not mean that the Colonists were justified in what they did-but the rigid refusal to admit that there was any possible extenuation of their conduct seemed to me very hard measure. In reading your narrative and accepting every part of it as absolutely just, the Puritans would seem to have committed a wanton, causeless crime for which there was not only no motive, but which considering the contrast in the characters of the two sachems was wholly inconsistent with the safety of the colony. It is true that you now state a motive which they might have had and which you on the authority of Savage ${ }^{3}$ ascribe to them, namely that Miantonomo was to be punished for having sold land to Gorton. ${ }^{4}$ I confess that I am much better satisfied that the act should be put on this ground than that it should be left as it seems to me your narrative leaves it-without even the excuse of religious fanaticism-a poor excuse to be sure, but still a strong and I admit over mastering motive with the Massachusetts colonists. If on considering what I have said you see no cause to speak 
of any possible extenuation of their conduct I hope you will at least give them the benefit of this probable motive in a note or some other way.

Yours very truly

W C BRYANT.

\section{Proof Sheet}

Page 10021 st line from top "about it" should it not be "about the matter"-else it may refer to testimony as its antecedent.

" 104 Line 11th from top the sentence beginning "Equally clear" \&c should form a part of the previous sentence separated by a semi-colon.

" 115 Last line of the text but one. Is the language here quoted as that of Winthrop precisely as he said it? Did he not say "has" for "had" and "will" for "would"?

" 116 Line 13 from top and following "it was decided in Boston" \&cc. But it does not appear that it was so "decided." Winthrop only said that "these informations might arise out of a false ground, not that they did so. His language leaves the matter in doubt. I do not, on carefully reading your account of the capture and execution of Uncas think that perfect justice is done to Winthrop and his associates clerical and lay. It seems to me that there was a real fear of the captive chief, and in one place it is admitted that "they did not believe it would be safe to set the Sachem at liberty"-in other words that they believed the testimony against him-Please consider whether there cannot be some modification of the extreme severity of the conclusions arrived at which make the slaying of Uncas an atrocious murder.

Observations on the Chapter entitled Rhode Island and Providence Plantations.

Page 1st line 6 from the bottom "jubilant" The word signifies noisily exultant Is that a true representation?

" $\mathrm{x} 4$ A parenthesis and a bracket inside of the parenthesis and the abbreviation O.S.-These marks and abbreviations are inelegant in the text of a history.

" x10 line 24 from the bottom the words "put upon." I do not know precisely what is meant by them-probably something like "insulted"-but is that a proper use of the phrase? 
" 14 lines 19, 21 \&c from the top. "give me [him"] This is an awkward way of making a quotation and cannot be read aloud without creating a confusion of the sense. If the sentence was turned thus it would avoid the awkwardness: "I was," he adds "caused to pray earnestly" \&c \&c and then the [him] might be omitted.

x 16 The conclusion of the note on this page strikes me as expressed, with excessive acrimony, whether the terms applied to Dr. Dexter ${ }^{5}$ be deserved or not they are such [as] will naturally provoke a controversy. They amount to a charge of wilful falsehood, and I do not wish to be answerable, for that, as I shall be if the note stands as it is in the proof. What is to be done is to write the history of the United States-not to show that Dr. Dexter's work is a falsifcation of history. I do not object to the truth being stated in regard to the cruel treatment of Holmes. ${ }^{6}$ If that convicts Dexter of misrepresentation very well-let him bear the consequences-but it does not seem to me well to go beyond that and pronounce sentence upon him. In a preceding part of the same note it is said "both Palfrey? and Dexter see fit to omit this latter part of the sentence." I wish you would leave out the words "see fit to" for they seem to imply wilful mutilation of Holmes's account-a thing which I believe Palfrey incapable of. Please think of this with your usual quiet judgment.

Page $\mathrm{x} 18$ There is near the bottom of this page a sentence enclosed in brackets-awkwardly it seems to me, when it might better be taken out of the place where it is embracketed and put at the end of the paragraph.

Cummington Sept 3d 1877.

There are one or two corrections in pencil

Observations on Chapter A.-

New Netherland under Peter Stuyvesant

Page 202 near the bottom "emollient"- this word is always used in an active sense signifying something that softens-mitigates but here it is made to do a different duty.

" 209 In the note is "Augustine" the true Dutch orthography of the name? ${ }^{8}$

" 218 Line 11 from top [brewenes run?] 
Line 13 from bottom "brought to [unwonted?] submission to permit the departure" \&cc an awkward construction.

" " Line third from bottom "left" better "left the colony"

MANUSCRIPT: CU ADDRESS: S. H. Gay Esq.

1. Omission Bryant's; Gay's letter is unrecovered.

2. The Mohegan Indian sachem Uncas $(c 1588-c 1683)$, allied with the Narraganset chief Miantonomo in a war against the Pequots, treacherously murdered his late associate in 1643, with the approval of the English colonists.

3. James Savage, editor in 1853 of John Winthrop's The History of New England from 1630 to 1649 .

4. Samuel Gorton (1592-1677), the leader of a dissident religious sect in conflict with the leaders of the Massachusetts colonies, who settled Shawmut, Rhode Island, later renamed after his patron, the Earl of Warwick.

5. Probably Henry Martin Dexter (1821-1890), editor of the Congregationalist from 1851 to 1890 .

6. Obadiah Holmes, a Rhode Island Baptist minister, who was persecuted and beaten in 1651 by Massachusetts Puritans. 1890)

7. John Gorham Palfrey (1796-1881), author of a History of New England (1858-

8. Probably a reference to Augustine Heermans, listed as one of nine popular legislators in the New Netherlands colony. See Bryant, Popular History, II, 123n.

2514. To Charles E. Smith

[Cummington] Sept 10th 1877.

I am greatly obliged to the members of the Massachusetts Bryant Club for the honor they have done me in taking my name when so many another and more brilliant were before them for their choice. ${ }^{1}$ Will you please to communicate to them my thanks for a distinction which I have done so little to earn and my good wishes for the prosperous and satisfactory working of their association. I learn from you that the first selection read before the club was a poem of mine entitled "The Flood of Years." The Club has perhaps done well in this since an humble beginning often leads to a noble ending. We enter by easy lessons on the highest and most difficult branches of learning and science, and whoever would climb a ladder must begin with the steps nearest the ground.

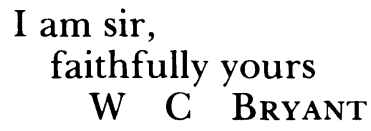

MANUSCRIPT: NYPL-GR (draft) ADDREss: Chas. E. Smith / [ ? ] the club / is in North Brookfield. ENDORSED (by Bryant): Chas. E. Smith of / Boston-about the / Massachusetts Bryant Club in / North Brookfield / Sept. 5th 1877.- 
1. Smith, a Boston lecture bureau agent, and president of the "Massachusetts Bryant Club," had written on September 5 (NYPL-BG) asking for an autograph letter to be read before the club, which was located in the town of North Brookfield, where Bryant had studied Latin with his uncle at the age of fourteen. See Volume I, 18, 20.

2515. To Sydney H. Gay

Cummington, Massachusetts September 11 th. 1877.

Dear Mr. Gay.

I am glad that you have delivered up your victim Dr. Dexter, with so good a grace. You have proved him to be in the wrong without calling him a liar. As to Mr. Palfrey, it is the most natural thing in the world that he should have wished to find the Puritans, his ancestors, clear from blood-guiltiness, and you know how far such a prejudice will carry one, and how blind it will make him to what others see plainly, without any design on his part to put a false face on the facts of history. I am glad that you accept my way of disposing of the note in question, for if it had been printed as first written it would have given me many moments of discomfort. As to the facts, you know me well enough to be sure that I would have them related without disguise, and that if they are unpleasant to any body, I look at the matter in this light-that the fault is in the facts and not in him whose business it is to relate them.

Yours very truly,

W. C. BRYANT

MANUSCRIPT: CU ADDRESS: S. H. Gay Esqr.

2516. To C. C. Goss ${ }^{1}$

Cummington, Mass. September 18, 1877

... I have your obliging letter of the 13th of this month. ${ }^{2}$ I have written to a friend to look up and send you a little volume of hymns, ${ }^{3}$ in which you will find the one referred to by you, with the readings in their latest form-you will judge for yourself whether they are the best. In regard to the tune, I have no preference. The hymn was written in Great Barrington, Massachusetts, in the year, or about the year, $1822 .{ }^{4}$ In the meantime allow me to congratulate you and your friends on the plan which you have adopted in making up your compilation and to thank you for the honor done me in giving a place to one of my compositions. ... 
MANUSCRIPT: NYPL-Berg (partial) ADDRESS: Rev. C. C. Goss.

1. Unidentified.

2. Unrecovered.

3. Bryant, Hymns (1864).

4. One of five hymns Bryant had composed in 1820/1821 for a Unitarian hymnal, at the suggestion of Catharine Sedgwick. See Letter 63.

\section{To Leonice M. S. Moulton}

My dear Mrs. Moulton.

Cummington, Sept. 19.1877.

Yours of the 17 th $^{1}$ reached me last evening. I am sorry that you left this place out of your travels. It is a little ungrateful in you thus to neglect a place which has treated you and your daughter so well. My grand daughter Fanny has just left us, a great deal stronger and plumper than when she came and a breath or two of this invigorating [air?] ${ }^{2}$ would not have been wasted I think on the lion tamer herself.

You ask us to tell you all about our party here. Julia is getting a little stouter. My brother [John] seems in better health than usual. Miss Dickson left us ten days since all the better for her sojourn. Since then we have had a visit of three or four days from Mrs. Mitchell ${ }^{3}$ and another of like duration from Mrs. Mackie. ${ }^{4}$ Yesterday Miss [Jerusha] Dewey came and will remain here unless she changes her mind, until we set out for Roslyn, which/D.V., will be two weeks from yesterdaythat is to say, on Tuesday of the week after next. In the mean time I have been kept busy in planning some small improvements, and watching their progress, answering applications for my autograph, and for my opinion as to the merits of manuscript poems sent me, and writing a hymn - a temperance hymn for the new Methodist Hymn Book,-a hymn which Mr. David Creamer, the hymnologist, says, is the best temperance hymn which was ever written or ever will be, until I write another. ${ }^{5}$ These occupations, with what time I give to the History, and a little reading, fill up the time from morning till we are all sleepy again - Looking over what I have written I see that I have left out the drives and walks which it is a pity that you are not here to help us take, and in which particularly the drives Julia bears her part. But let me distinguish. My brother and I do most of the walking, and Julia and her female friends most of the driving out. I do not often get into a carriage.

My fruit trees which I planted almost as soon as I came in possession of the old homestead begin to produce what was expected of them. The plum trees this year have done their duty and the pear trees are not behind them; the only thing to be desired is that there should be some of earlier sorts. One thing which I have done since I 
came hither is to read two or three of my poems to the worshippers in the orthodox Congregational Church in the West Village, at the request of the minister. ${ }^{6} \mathrm{He}$ wished it to take the place of the morning service-but to that I would not consent-so the service was shortened, and I read "Thanatopsis," the lines "To a Waterfowl," and "Waiting by the Gate" with some comments.

So you have here a history of what I have been doing since I came. Of the place and its surroundings I have this further to saythat the blackberry crop has been scanty, which is ordinarily so abundant. At this time the berries are in ordinary years, at their ripest and sweetest-but this season, I believe the very last of them have been already picked. Nor is it the children and the birds only that gather them, but the squirrels take their part-a proof of which I have seen with these eyes. I remember once travelling with an Irish gentleman, a lawyer settled at St. Louis, who said, what I never heard before or since, that on the Connecticut river in New Hampshire there was a great deal of fever and ague. I hope you will not catch it at Hanover. ${ }^{7}$

\section{I am, as ever, truly yours \\ W. C. BRYANT}

MANUSCRIPT: NYPL-Bryant-Moulton Letters ADDRESS: Mrs. L. M. S. Moulton.

1. Unrecovered.

2. Word omitted.

3. Bryant's niece Ellen Shaw Mitchell (738.1).

4. Estelle Ives Mackie (1101.1).

5. David Creamer (1812-1887) was a Baltimore author, publishing in 1848 Methodist Hymnology, a study of John and Charles Wesley's poetry. Bryant's hymn was probably "The Captive Loosed." See The Poetical Works of William Cullen Bryant, Roslyn Edition (New York: Appleton, 1907), p. 366.

6. Ozias S. Morris (1821-1885), pastor of the West Cummington Church from 1873 to 1881. Only One Cummington, p. 400; Vital Records of Cummington, p. 211.

7. Among his many offices, Mrs. Moulton's foster son John Ordronaux was a professor of medicine at Dartmouth College from 1864 to 1903.

2518. To S. H. Cohen ${ }^{1}$

Dear sir.

Cummington, Massachusetts. September 22d 1877.

You ask me to state the difference of meaning between the words outward and external. In many cases they are used as meaning the same thing; in others they do not. The particle "ward" added to "out" seems to imply motion towards some object or place, as "this door opens outward" or "the light of this lamp streams outward through the window." There is also the word outer, which often may be substituted 
for "external," but when we say "the outer gate" we cannot change it for "external"- "the outer gate" means the gate further out than others, and implies comparison. In none of the cases I have mentioned can "external" be used. You see therefore that there is a difference in many cases, while in others the meaning of the two words is the same.

Yours faithfully

WM. C. BRYANT.

MANUSCRIPT: DuU ADDRESS: Mr. S. H. Cohen.

1. Unidentified. No query from him has been recovered.

2519. To Sydney H. Gay

Dear Mr. Gay.

Cummington Sept. 24, 1877.

I find that when I animadvert upon what you have written you almost always get the better of me-which considering that you carefully study what you are about to write is not surprising. Nevertheless I think that you are right in letting the reader in certain cases, as you have expressed yourself in your last, have all the facts before him and form for himself the judgment which they force upon him.

I feel in the mean time almost uncomfortable with the reflection, that I can do little more than supervise the semi colons and commas and such like. The chapter I send with this is spirited and characteristic- Two or three verbal changes are suggested-trivial as they are, in what I have written on the other part of this sheet. ${ }^{1}$

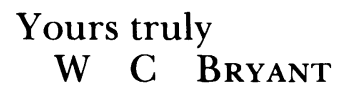

MANUSCRIPT: CU ADDRESS: S. H. Gay Esq.

1. This chapter is undetermined.

2520. To the Editors of the International Review.

Cummington, Massachusetts. September 26th 1877.

Gentlemen

I have sent you herewith the Sonnet in Memory of Mr. Motley, ${ }^{1}$ and hope it will answer your purpose.

Yours truly

W. C. BRYANT.

\section{In Memory of John Lothrop Motley. ${ }^{2}$}

Sleep, Motley, with the great of ancient days, Who wrote for all the years that yet shall be. 
Sleep with Herodotus, whose name and praise Have reached the isles of earth's remotest sea.

Sleep, while, defiant of the slow decays Of Time, thy glorious writings speak of thee And in the answering heart of millions raise The generous zeal for Right and Liberty. Sleep, till the days o'ertake us, when, at last, The Silence that ere yet a human pen

Had traced the slenderest record of the past Hushed the primeval languages of menUpon our English tongue its spell shall cast. Thy memory shall perish only then.

William Cullen Bryant.

MANUSCRIPT: YCAL ADDRESS: To the Editors of the International Review.

1. The historian John Lothrop Motley (1814-1877, Harvard 1831) had died earlier that year. This rare exception to Bryant's refusal to write occasional verses on request may be accounted for in part by his admiration for Motley as a champion of freedom, and in part by the indignation he had expressed in the EP in November 1870 when President Grant summarily recalled Motley from his post as minister to Great Britain.

2. First published in the International Review for November-December 1877, and collected in Poetical Works, II, 349.

2521. To Sydney H. Gay

Dear Mr. Gay.

Roslyn L.I. October 8th 1877.

You have treated the ugly affair of the execution of Miantonomo admirably, ${ }^{1}$ and after reading the revised account of it in the proof sent me I find that I have a much clearer idea of the merits of the question and the motives by which the colonists were actuated than I had before. After all the conduct of the Puritans in that case was no more to be justified than the murder of a prisoner of war would be in modern times. The truth must be told and you have told it nakedly, in such a manner that the readers of the history will have no difficulty in making up their minds as to the moral quality of the act.

Yours truly

W C. Bryant.

Chapter B.B.- a dreadful chapter [II, viii]

Page 003 "minister to their humility" - what does it mean? low estate perhaps. 
" " "go to service" ordinarily means to become a servant-it seems to me not well used for "attend religious worship"-

" 005 By all means I would omit the sentence cancelled on this page.

006 "is replete" means too much-say abounds.

008 A grammatical slip which I have corrected.

009 "The following episode." The episode does not followonly the recital of it follows.

010 "noble" would it not be better left out-the reader to judge for himself as to the quality of the saying?

011 "repudiated" better disowned.

015 A document is here given-I hesitate in regard to it. The appendix is the place for documents as a rule. What do you think?

" 017 "John Woolman"2 after the name insert "many years afterward," else it will seem to the general reader that you speak of an event contemporary with the persecution.

" 018 "leniency" should be lenity.

" 020 "can" should not it be could?

" 021 "a delightful bit of legal tautology" - not so ridiculous as to deserve such a comment which were better omitted.

Page 022 "to the effect that"-better "in these words."

025 "set on" Why not persuaded or instigated?

028 "considerably insulted," Cannot this be improved?

031 "much put him out"-is not disturbed him better?

033 "did propose"-why not proposed?

" 034 "prohibition of" \&c for clearness the "of" needs [repe?]tition.

MANUSCRIPT: CU ADDRESS: S. H. Gay Esq.

1. See Letter 2513.

2. John Woolman (1720-1772) was a Quaker mystic who traveled widely throughout the American colonies. He kept a notable Journal, published in 1774, which was praised by Charles Lamb and John Greenleaf Whittier. He was an early antislavery writer and defender of the poor.

2522. To Fred R. Doerinckel ${ }^{1}$

Dear Sir.

Roslyn Long Island N.Y. October 15th 1877

I thank you for the honor you have done me in setting to music one of my poems, and for the German translation which appears to me to be skilfully done. ${ }^{2}$ I have received the copy which was sent for 
me to the office of the Evening Post and for which please accept my acknowledgments. I certainly shall be gratified to know that you have laid it before the musical public with the air to which you have adapted it and with the German verses.

$$
\begin{aligned}
& \text { I am, sir, } \\
& \text { very respectfully yours } \\
& \text { WM. C. BRYANT. }
\end{aligned}
$$

MANUSCRIPT: UVa (facsimile?) ADDRESS: Mr. F. R. Doerinckel. York.

1. A music publisher with offices at 211 and 213 East Twenty-third Street, New

2. Bryant's poem was "The May Sun Sets an Amber Light," written in 1849 in memory of his mother, who had died two years earlier. Neither the music score nor the German words have been located.

2523. To Julius Nathan ${ }^{1}$

Dear Sir.

Roslyn, Long Island

October 26th 1877.

Mr. John R. Thompson was never the Editor of the Evening Post, but an associate editor, and was employed for the most part in the literary department. ${ }^{2}$ Part of the editorial articles were written by him.

Yours respectfully

W. C. BRYANT

MANUSCRIPT: University of Chicago Library ADDRESS: Mr. Julius Nathan DOCKETED:

W. C. Bryant / Ed. Eve Post.

1. Unidentified, except as in Letter 2528.

2. Thompson (1951.3) had died in 1873. Nathan's enquiry is unrecovered.

2524. To Lucy Webb Hayes ${ }^{1}$

Dear Madam.

Roslyn, Long Island N.Y. October 31st 1877.

Allow me to introduce to you, at her special desire, the bearer of this note, Miss Margaretha [W?]eppner, a young German lady who has been remarkable among her sex for the extent of her travels, having made the tour of the globe alone, and having published an account of her journeys and the observations which they gave her the opportunity of making. ${ }^{2}$ She passed the winter before last in the City of New York and was introduced to me by Mr. Peter Cooper who took a friendly interest in her success as an author.

I am, Madam, very truly yours.

W. C. BRYANT 
MANUSCRIPT: RBHL ADDRESS: To Mrs. Rutherford B. Hayes.

1. Lucy Webb Hayes (1831-1889) was the wife of President Rutherford B. Hayes.

2. Friendly and outgoing, Mrs. Hayes instituted regular public receptions in the White House, at which she was 'especially cordial toward 'ladies of the press,' and freely granted them invitations and interviews." Kenneth E. Davison, The Presidency of Rutherford B. Hayes (Westport, Connecticut: Greenwood Press [1972]), pp. 75, 83-85. The subject of Bryant's letter has not been further identified.

2525. To James G. Wilson

Roslyn, Long Island N.Y. October 31st 1877.

My dear sir.

Mr. Story's eminence both as a poet and a sculptor, deserves the acknowledgment which you and your friends are about to make. ${ }^{1}$ I however, in my old age, live here so retired, and I am so apt to be disturbed by petty inconveniences that I never, except on occasions which I cannot well put aside, come into town to stay all night, as I must do in order to be present at the banquet of which you speak. You and the others will therefore, I am sure, consent that I should admire the evidences of his genius at this distance, equally with those who are present at the banquet. ${ }^{2}$

Yours very truly, W. C. Bryant.

MANUSCRIPT: NYPL-Berg ADDRESS: To Gen' James Grant Wilson.

1. Bryant had been entertained by Mr. and Mrs. William Wetmore Story at Rome in 1858; see Letter 1031.

2. Although Bryant didn't attend a dinner given Story at the Union League Club on November 15, on the occasion of one of his infrequent visits to his native country from his residence in Rome, the list of twenty-five prominent men who extended the invitation was headed by Bryant's name. See Letters 2531, 2532.

2526. To Paul H. Hayne

My dear Sir.

Roslyn, Long Island N.Y. November 1st 1877.

I accept with pleasure the honor you offer me-the dedication of your poem entitled "Unveiled."

I do not wonder that you speak of it in affectionate terms, for it is written with a genuine poetic enthusiasm.

I am, dear sir, truly yours.

W. G. Bryant. 
MANUSCRIPT: DuU ADdRess: To Paul H. Hayne Esq.

1. The rather fulsome verses with this title appear in Poems of Paul Hamilton Hayne. Complete Edition (New York: AMS Press [1970]). Reprinted from the edition of 1882, pp. [219]-222. No specific dedication to Bryant is there indicated. Four years earlier Bryant had responded generously to an appeal for help from Hayne, who had lost his home, library, and most of his other possessions during the Civil War through fire or pillage from federal troops. See Letter 2156.

2527. To Teresa Arnold ${ }^{1}$

\section{Dear Miss Arnold}

Roslyn, Long Island N.Y. November 3d 1877.

The story which you have heard about my leaving college is altogether untrue. I had been matriculated at Williams College and left it intending to go to Yale-for which in the mean time I had prepared myself by study, without an instructor, except my elementary books. My father then told me that some reverses in his circumstances rendered it impossible for him to defray the expense of my plan, and it was accordingly abandoned. ${ }^{2}$ The poem of which you speak was not then published or spoken of. ${ }^{3}$

Yours respectfully, W C BRYANT.

MANUSCRIPT: Sleepy Hollow Restorations ADDREss: Miss Teresa Arnold.

1. Unidentified.

2. See Volume I, 18; Letters 4, 5 .

3. No enquiry from Miss Arnold has been recovered.

2528. To Victor Wolff and Julius Nathan

Gentlemen,

Roslyn, Long Island N.Y. November 3d 1877.

Allow me to thank the members of the Chester Literary Union for adopting me as an honorary member, and for the kind wishes expressed in the resolutions which you have sent me. ${ }^{1}$ The honorary membership I accept with pleasure.

I am, gentlemen, faithfully yours.

W. C. BRYANT.

MANUSCRIPT: ACL ADDREss: To Mr. Victor Wolff President and / Mr. Julius Nathan Secretary / of the Chester Literary Union.

1. Unrecovered. 
2529. To James Sutten ${ }^{1}$

Dear sir.

Roslyn, Long Island N.Y. November 5th 1877.

The Green River, which gave its name to my poem,${ }^{2}$ is a beautiful little stream of Berkshire County Massachusetts. It flows through Great Barrington, passing by the dwelling of Mr. Mackie, author of Casas de Españ $a,{ }^{3}$ and entering the meadows of the Housatonic pours itself into that river.

Yours truly

W. C. BRYANT.

MANUSCRIPT: StUL ADDRESS: James Sutten Esq.

1. Unidentified.

2. First published in 1821. See Poems (1876), pp. 31-35.

3. John Milton Mackie (1101.1), Casas de España, or Going to Madrid Via Barcelona (New York, 1855).

2530. To William Penn Lyon ${ }^{1}$

Roslyn, Long Island, N.Y. November 7th 1877.

My dear sir.

I thank you for your ingenious letter ${ }^{2}$ describing the four stages of life in the instance of one who has reached eighty four years. It is ingenious and has entertained me greatly. I only wish that I could even, in the most distant manner, give an example of the qualities which you ascribe to the two later stages.

I am sir very respectfully yours.

W C. BRYANT

MANUSCRIPT: Sleepy Hollow Restorations ADDREss: $\mathrm{W}^{\mathrm{m}}$ P. Lyon Esqre. / Crescent Hedge / Bloomfield / New Jersey.- POSTMARK: NEW YORK / NOV 7 / 630 PM.

1. William Penn Lyon (1822-1913) was a lawyer, Union soldier, and Wisconsin legislator and jurist.

2. Unrecovered.

2531. To William Wetmore Story

Dear Sir:

New York

November 10, 1877.

Although you have been long absent from your native land, your fellow countrymen have watched your career with pride and pleasure, 
recognizing that your renown in the art to which you have devoted your life is an added lustre to the American name.

A few of your friends and admirers in New York desire to express, in a social and informal way, their high regard for you, and we therefore beg that you will give us the honor of your company at dinner at the Union League Club, on Thursday, November 15, at 7 o'clock.

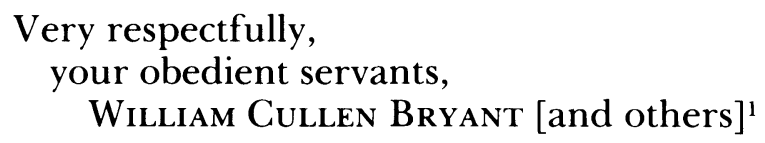

MANUSCRIPT: Unrecovered TEXT: Unidentified newspaper clipping, probably from the EP.

1. Bryant's name headed a list of twenty-five prominent New Yorkers as signers, including George W. Curtis, John T. Johnston, Theodore Roosevelt, Sr., Joseph H. Choate, Frederick L. Olmsted, Daniel Huntington, John Jay, and John Bigelow.

2532. To the Committee of Arrangements for the Dinner to Mr. Story. Roslyn Long Island N.Y. November 12th 1877

Gentlemen,

I cannot be present at the banquet given to Mr. Story, eminent like Michael Angelo, in the sister [arts?] ${ }^{1}$ of sculpture and poetry. But I can admire his genius and his works in both these arts, as warmly in this retreat, as if I were with you to hear the words in which he will be welcomed to the chief city of his native country.

I am, gentlemen, faithfully yours.

W. C. BRYANT.

MANUSCRIPT: YCAL ADDRESS: To the Committee of Arrangements for the Dinner to Mr. Story.

1. Word omitted.

2533. To Edward Abbott ${ }^{1}$

Roslyn, November 17th [1877]

... I should be glad to celebrate in verse the seventieth return of John Greenleaf Whittier's birthday, ${ }^{2}$ if the thoughts and words fitting for such an occasion would come at call to be arranged in some poetic form, but I find that I must content myself with humble prose. Let me say, then, that I rejoice at the dispensation that has so long spared the world a poet whose life is as beautiful as his verse, who has occupied 
himself only with noble themes, and treated them nobly and grandly, and whose songs in the evening of life are as sweet and as thrilling as those of his vigorous meridian. If the prayers of those who delight in his poems shall be heard, that life will be prolonged in all its beauty and serenity for the sake of the world which is the better for his having lived, and far will be the day when all that we have of him will be his writings and his memory....

MANUSCRIPT: Unrecovered TEXT (partial): Life, II, 387.

1. Probably Edward Abbott (1841-1908), rector of Saint James Episcopal Church, North Cambridge, Massachusetts, and editor of the Literary World, 18781888 and 1895-1903.

2. Abbott's invitation, unrecovered, was apparently to compose verses to be read at a dinner, held at the Brunswick Hotel in Boston on December 17, 1877, to mark both Whittier's seventieth birthday and the twentieth anniversary of the founding of the Atlantic Monthly. This occasion, often recounted, was notable for a contretemps brought about by the speaker of the evening, Mark Twain, who made here his first appearance before the Boston-Cambridge literary giants, among them guests of honor Emerson, Holmes, and Longfellow. Twain read a skit he had written for the occasion, telling of "three ill-favored tramps masquerading under the names of Longfellow, Emerson, and Holmes [who] visited a California miner's cabin [and] made what Twain regarded as very amusing use of certain verses by their namesakes, and, in general, behaved in [an] ungentlemanlike manner." Apparently the speech was received in an embarrassing silence, and Twain was afterward so contrite that he wrote letters of apology to the subjects of his humor. When Howells assured him that no one had taken real offense, Twain is reported to have written this friend that he "felt as relieved as had the Missouri woman when her baby turned out white." See Ralph L. Rusk, The Life of Ralph Waldo Emerson (New York: Scribner's, 1949), p. 500; Kenneth E. Eble, Old Clemens and W. D. H.: The Story of a Remarkable Friendship (Baton Rouge \& London: Louisiana State University Press [1985]), pp. 92-96. Mark Twain's skit, "The Whittier Birthday Speech," may be found in The Complete Humorous Sketches and Tales of Mark Twain, ed. Charles Neider (Garden City: Doubleday, 1961), pp. 345-349.

2534. To F. B. Sparks ${ }^{1}$

Roslyn Long Island N.Y. November 21, 1877-

\section{Dear Sir.}

Soon after the receipt of your letter informing me of the honor done me by the "Law and Order League of the City of New York" in electing me as its President, ${ }^{2}$ I learned that there is a serious misunderstanding between that association and the one "for the Suppression of Crime." I do not inquire whether there is any due occasion for it, but as I understood at the first that there was no disagreement between those who were at the head of these associations, and as I do not wish to be concerned in any such misunderstanding, I find myself obliged 
to decline an honor which I at first intended to accept, with thanks for the distinction.

$$
\begin{aligned}
& \text { I am, sir, truly yours } \\
& \text { W C BRYANT. }
\end{aligned}
$$

MANUSCRIPTS: MinnPL (final); NYPL-GR (drafts) ADDREss: F. B. Sparks Esq / Secretary of the League \&c.

1. Identified in descriptive note.

2. Letter unrecovered.

3. In a letter of the same date (NYPL-BG), Howard Crosby (1826-1891), pastor of the Fourth Avenue Presbyterian Church in New York, and founder of the Society for the Prevention of Crime, wrote Bryant, "Seeing that the so-called 'Law \& Order League' has elected you President, I feel it but proper (supposing that you know nothing of its history) to tell you that it is a company formed in rivalry of our 'Socy for the Prevention of Crime,' \& managed by a few indiscreet men, one of whom has been held up to reprobation by the press, while his chief witness is a convict. It seeks to make a commotion \& gain notoriety by attacking respectable hotels, while the aim of our Society is to suppress the groggeries whence, the Police assure us, nearly all the rowdyism in the city originates. I am quite sure that you will not allow your revered name to be used by the organization referred to."

2535. To William Oland Bourne ${ }^{1}$

Roslyn, Long Island N.Y. November 23d 1877.

Dear Mr. Bourne.

I have great confidence in what you say, but I cannot bear to be involved in any misunderstandings of other people. Those which I myself occasion, suffice for me, and I learn from a note which I have just received from Dr. Crosby, that in the case of the Law and Order League, the misunderstanding is a serious one. I have therefore just addressed to Mr. F. B. Sparks the Secretary protem of the League a note declining the Presidency.

Yours truly

W. C. BRYANT.

MANUSCRIPT: MinnPL ADDRESS: William Oland Bourne Esq.

1. Identified only as an officer of the Law and Order League.

2536. To Howard Crosby

Dear Sir.

Nov $24 \quad 1877$

I am sorry that any want of good understanding exists between the two associations referred to in your letter. I do not care to step 
into a misunderstanding already existing-and I have therefore written the Secretary pro tem of the Law and Order League declining the presidency.

\section{W C Bryant}

MANUSCRIPT: NYPL-GR (draft) ADDRESS: To Dr H. Crosby.

2537. To Sydney H. Gay

Dear Mr. Gay.

Roslyn, Long Island N.Y. November 26th 1877.

I send back the proof of the twentieth chapter ${ }^{1}$ of the History which is an interesting chapter, and made up of incidents skilfully related. I have made the few observations on it which you will find on the other part of this sheet.

Yours truly, W. C. Bryant.

\section{Chapter XX[I]}

Page 003 Mesnard "lost his life" It seems to me that this should be more particular. The reader is not satisfied and inquires Was it by accident or an encounter with the Indians[?] ${ }^{2}$

same page

"Totem of the Sioux \&cc It seems to me that there should be some explanation of the word totem-say emblem or symbol-or explain in a note.

Page 008 For "notion"-it is better to read "hope" which is the word to which notion refers.

" 010 "in the head" Qu? on the head?

" 014 "when they sailed" qu: after which they sailed?

" 013 "cement alliances" to cement an alliance is to strengthento confirm-but here it is meant only to form alliances.

There are two or three little suggestions made besides these, on the proof in pencil.

MANUSCRIPT: CU ADDRESS: S. H. Gay Esq.

1. Chapter XXI, as published.

2. A Jesuit priest, Father Mesnard, who founded an Indian mission on the southern shore of Lake Superior in 1681, later died near Lake Huron of undetermined causes. 
2538. To John H. Gourlie

Roslyn, Long Island N.Y. November 26. 1877.

Dear Gourlie.

If you had consulted Worcester ${ }^{1}$ you would have found an answer to your inquiry. ${ }^{2}$ In that dictionary "Hebberman" is defined as one who at low tide fishes for whitings, smelts \&cc. There is, also the word Hebbing-wears which is defined "Devices or nets laid for fish at ebbing time." It seems to me that here the word ebbing shows clearly the derivation of hebberman." The letter $h$ is added to the word "ebb" and this gives the etymology. ${ }^{3}$

Yours very truly

W. C. Bryant.

MANUSCRIPT: Collection of Edith C. Gourlie ADDREsS: John H. Gourlie.

1. Joseph Emerson Worcester, A Dictionary of the English Language (1860).

2. Unrecovered.

3. The Oxford English Dictionary describes Hebberman as a variant of Ebberman, he who "hems in fish with nets so that they cannot go back to sea with the ebb tide."

2539. To Fanny Bryant Godwin

\section{Dear Fanny}

New York Dec 4. 1877.

Yesterday Mr. Wm Henry Lewis ${ }^{1}$ of Westbury [Long Island] called and desired to make a statement in exculpation of himself. He had held himself ready to go with you whenever you pleased to appoint and see a certain old clock which he owns and had supposed that you might purchase. But as he had received no notice of the time at which you would call, and as his business required him to be absent much from his house, he was unfortunately away when you called and you were consequently disappointed and did not see the clock and he was also disappointed of a purchaser. The clock is there yet and he would be glad to let you see it whenever you pleased to appoint a time. He will paint the case and put every thing in order and let you have it for forty five dollars-or if you take it as it is-the price will be somewhat less.

Yours affectionately

[Unsigned]

MANUSCRIPT: NYPL-GR ADDRESS: Mrs. F. Bryant Godwin.

1. Not further identified. 
2540. To Sydney H. Gay

Dear Mr. Gay.

New York Dec. 5th 1877.

I return the proof of Chapter C. with a remark or two. Old Peter Stuyvesant ${ }^{1}$ made of Life in the Dutch Colony a stirring time.

Page 201 It appears to me that the precise date of the attack on New Amsterdam by the Indians ${ }^{2}$ should be given in the textYou say "early morning" What month?

Page 204 opposite the first pencil mark- "effective" for effectualsecond mark-"professed submission" submission is not what they professed but peace-they were not subjugated but pacificated.

" 207 last line- You say at "high noon" why not the day and month?

" 209 Such uniformity - This use of such seems to me peculiarly inelegant-Why not this instead?

" 210 "Such doctrine" "Such" for that.

" 212 "Such" for this again

" 214 "And" at the beginning of a sentence here seems to me better omitted

" 215 first pencil mark - Is "stolid," which is a contemptuous term the right word?

" 216 "Hatred" qu: ferocity.

Yrs truly W. C. BRYANT ${ }^{3}$

“Chapter C” [Volume II, Chapter X] MANUSCRIPT: CU.

1. Petrus Stuyvesant (1610-1672), last Dutch governor of New Amsterdam, 1647-1664.

2. An attack on New Amsterdam in 1655 by a large body of Indians from tribes adjacent to the colony.

3. The notes and comments which follow are unaccompanied by covering letters; they are presented insofar as possible in numerical sequence of chapters in Volume II of the Popular History.

\section{Chapter IX}

Galley 1 "condition of the colony then and when" \&tc might be improved-it stopped me and I had to read it again.

" 2 "He hardly lived except by strength of will" is very elliptical.

" " Naseby ${ }^{1}$ had been fought-another ellipsis

" 3d "untiring" I have a prejudice against that word as capable of a double signification and not so good as "unweaned"

" 4 I have altered abuse to abase I suppose rightly 
" 6 "case" for cause-we plead a cause.

" 7 "He would not have held office $\mathrm{x} \times \mathrm{x}$ was the tenor of his speech"-should not that come before "he"?

" 8 "was" for but.

[Volume II] Chapter IX MANUSCRIPT: CU.

1. A village in Northamptonshire, England, where in 1645 forces of King Charles I were decisively beaten by those of Oliver Cromwell.

Suggestions in regard to the accompanying Chapter. [Volume II, Chapter IX?]

Page 003 "how mad it would have been" \&c To say it is mad to do a certain thing seems to me not quite right For "how mad" I suggest "what madness."

Page 008 "It was not that God cared much about Virginia" I suggest the omission of this. The reader will supply all that is necessary.

Page 017 "trammelled with passions and [touched?] by human weakness" The word trammelled does not seem to express the idea. To trammel is to fetter, to impede. The colonists were urged on rather than held back by human passions.

Page 021 "Enrolled" is wrong-"enlisted"?

"To this" in the $3 \mathrm{~d}$ note-strike out?

Page 023 Consider whether the whole passage about Naboth might not as well be omitted-beginning with the words "The good Governor."

Page 26 Before the words "to find" would not the words "in order" make the sentence neater?

\section{Remarks on Chapter D.}

Page 218 Is not nearness better than "propinquity"?

same "Disregarded the soldiers that guarded." Would not gave no heed to be better than disregarded[?]

" 219. "New Amstet"l I think-but may be mistaken-has not been mentioned before. If it has not there should be some explanation of where it is situated.

" 222 "his lordship" say Lord Baltimore. ${ }^{2}$ In the historical style we do not say his Majesty, but the king.

" 223. Opposite the pencil mark is a quotation which I can make nothing of. Is it right?

" 226 "bettered his instructions" does that mean went beyond them? 
" " "North River" or Hudson, which is the actual name of the River.

" 227 "abused them" abuse implies something wrong-reproached perhaps, or inveighed against

" 231 "anxious for the conquest \&c"- Is "anxious" the true word?-zealous or even desirous.

Page 232. "Those in favor" for those who favored, seems to me clumsy.

"Chapter D" [Volume II, Chapter XI] MANUSCRIPT: CU.

1. A colony of New Amsterdam on the Delaware River.

2. Cecilius Calvert, Second Lord Baltimore (1605-1675), who secured the first charter for Maryland Province.

\section{Chapter XII}

Galley 2d "March 1662 (old style 1663)" It seems to me that as the day of March is not given, the words in the parenthesis are not necessary-besides the fault of making a years difference between the old and New Style-when it is but 12 days.

" " "cattle and swine"-say neat cattle if it is wanted to distinguish them from swine.

" 3 "region of the country" the three latter words are superfluous.

" " "those then holding possession" ill sounding those who then held

" " "Yeamans" sometimes "Yeomans"l which is right?

" 4 "In trials by jury a majority was to decide" This is put in inverted commas as if literally copied from Locke. ${ }^{2}$ The word "was" shows that it cannot have been so copiedsame objection to other sentences.

(October 1667) Why not say in October \&cc and omit the parenthesis which has nothing to do there. "restrict"?

5 ("or Cape Romain)" no need of parentheses

6 "consequence" in Italics. There are hundreds of other words in the text equally deserving of Italics. Why here?

[Volume II] Chapter XII MaNUSCRIPT: CU. 1674.

1. Sir John Yeamans (1610/1611-1674), governor of the Carolinas, 1665, 1672-

2. John Locke (1632-1674, Oxford 1658), English philosopher best known for 
his Essay Concerning Human Understanding (1690), was also the author of a constitution for the Carolina colony (1669).

[Chapter XIII]

Galley 1st. "Ships that came out that Season" I suggest instead of that Season in 1666 or in the autumn of 1666.

$2 \mathrm{~d}$. "houses of better numbers" is that rightly quoted?

$3 \mathrm{~d}$. "greatly aroused" quere excited? Moved?

4 "deployed" disagreeably technical; why not sent? - or sent off or sent out

"Carolina, and who" omit the "and."

"pull"-why not pulled as the succeeding verbs are in the preterite?

" 6 "nor would it have profited to have held" a double past tense-say "to hold."

" " "to actually begin"-for actually to begin.

" 7 "untiring" an equivocal term.

[Volume II, Chapter XIII] ManUSCRIPT: CU.

\section{Chapter XIV}

Galley 1 "affairs of life returned to their usual channel" is not course better than channel?

2 "from Milford" say in Connecticut ${ }^{1}$ to distinguish the place from Milford in England.

3 ["commodiosest seate richest land"?] Is the quotation literally exact?

4 "castles" does not seem to me the proper name for the rude forts of the aborigines.

" 6 "tangle of water courses and marshes." tangle of water courses perhaps-but how of marshes?-A tangle is an inwoven knot.

near the bottom-"single dock" is not wharf more precise?

7 "which covered the point which lay below" too much like the house that Jack built. for "which lay below" read lying below.

" " Then comes a "tangle" of parentheses- For (Maiden Lane) read now Maiden Lane, ${ }^{2}$ without parenthesis and strike out the other parentheses, substituting commas.

" " So again omitting the parentheses prefix now to Gowanus ${ }^{3}$

" $"$ to Flatbush ${ }^{3}$ Jamaica $^{4}$ and Hempstead ${ }^{4}$-otherwise in reading them aloud the passage would not be intelligible. It seems to me that a neat style in history would bear reading aloud without the hearer missing the sense. 
Galley 7 "Arendt van Curler"5 - Is not "Curler" a corruption of the real Dutch Corlaer?

" " "replaced" \&c another useless parenthesis.

" 7 "pages of Knickerbocker" add -'s History of New York ${ }^{6}$ to distinguish it from another Knickerbocker-the magazine

" " "much oftener much covered" \&c Can this be as written?

Galley 10 "banished one and punished the other." Banishment is a punishment- Why not state the mode of punishmentfine flogging or imprisonment?

" " "compelled all" would not persons be properly added to all?

" 8th "in the exploration and occupation of the country" Cut off the long tails in "ation" and say in exploring and occupying the country

When "Charles" appears first on this galley it seems to me well to say Charles II. ${ }^{7}$

[Volume II] Chapter XIV MANUSCRIPT: CU.

1. In 1666 the site of Newark, New Jersey was settled by colonists from Milford, Connecticut.

2. An early street in New Amsterdam (fr. Dutch Maagde Padtje).

3. Long Island villages now absorbed in Brooklyn, New York City.

4. Villages in what are now Queens and Nassau Counties, respectively.

5. Arent Van Curler (1620-1667), Dutch colonial trader and founder of presentday Schnectady, New York.

6. Washington Irving, A History of New York by Diedrich Knickerbocker (1809).

7. Charles II (1630-1685), king of Great Britain and Ireland, 1660-1685.

\section{Remarks on Chapter XIV[?]}

Page 229 near the top. "an alarm** that the Dutch" \&c. It seems to me that we cannot say "an alarm that a thing is to be done"-we may say an alarming report or the like.

" 231 "for denouncing the Dutch for conspiring"-ill sounding at least. Lines $20 \& 21$ from top.

" 232 End of paragraph "both" should be "each."

" " Line 26 from top. "The new officers whom Stuyvesant insisted should be" false syntax.

" 251 "worms and insects" should it not be "worms and other insects"?

Chapter XV.

Galley 1 "trifling crimes" seems to me a contradiction petty offences? 


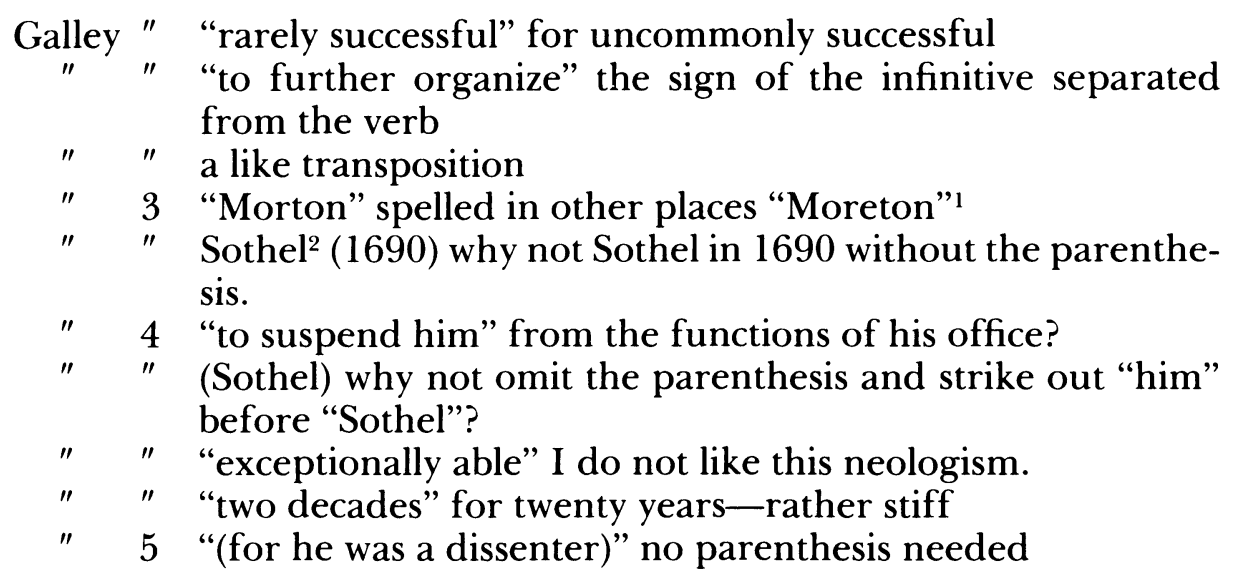

[Volume II] Chapter XV ManUSCRIPT: CU.

1. Joseph Moreton, governor of South Carolina, 1683, 1686-1687.

2. Seth Sothell (d. 1697), governor of North Carolina, 1678, 1683-1688, seized the government of South Carolina in 1690 and was removed from office the following year by the English parliament.

\section{Chapter XVI}

Galley 1 "recalled" referred to, I think, is better. "one now likely" [query?]?

"native powwow"l what does it mean? "quite a number," seems to me bad "preparing to leave" why not depart?

"Nicolls"2 spelt in two different ways. "part in a affairs" "to an act of" by an act?

5 "sumptuous" used here in a wrong sense. for ostentatious, or given to expense-a feast may be sumptuous-but not the giver of the feast. "tenacious," for tenacious of his purposes. tenacious alone may mean a physical peculiarity. "parties to be married," for persons "keenest recollections" seems to me faulty.

"beloved parchment hollow oak"? an [?]

"And the reports." Omit the "And" "And" again, superfluous and clumsy.

"achieve success and disaster" One cannot say achieve disaster

"Phips ${ }^{3}$ a failure" not absolutely wrong but a neologism, not quite history $=$ English. 
Galley 8 "an evidence of indomitable energy"-not so-of persevering energy if you please-but not of indomitable.

" " "to seriously impair", for seriously to impair

" " "ordered built" for ordered to be built.

" " "The measure was wise" I am not sure of that.

[Volume II] Chapter XVI MANUSCRIPT: CU.

1. An Algonquin Indian term meaning "medicine man," or "a consultation." First recorded in English by Edward Winslow in Good News . . . at the Plantation of Plymouth (1624).

2. Mathias Nicolls (1626-1688?), who came to New England in 1664 as secretary of a royal commission to investigate conditions in the English colonies.

3. Sir William Phips, American-born soldier who became royal governor of Massachusetts in 1692, and who then suppressed the witchcraft trials.

\section{Chapter XVII}

Galley 2d. "raiding" for attacking or something of the like meaning "affecting" should it not be disaffecting?

" 3d "driven" for driven off

" 4th "to learn from, and to better the teaching of," a case of splitting particles-instead to learn from his enemy and improve on what was taught.

" " "region of country" "of country" seems superfluous.

Galley 7. "Anxiety" \&c Is there not here in this paragraph an apparent discrepancy between the anxiety subsiding and "anxious anticipation"? or should not we say dread for "anticipation"?

" " "raiding" again-

" 8 "futile resistance"-futile is a somewhat contemptuous term-better vain.

" " "all the parties had not been posted" I am not certain of the meaning of this- Does it mean that all the parties of Indians had not been duly placed-or is parties used for persons and posted for informed?

" " "ambushed her" There is no authority for this use of the word ambush. Why not lay in ambush and leave out the pronoun?

[Volume II] Chapter XVII MANUSCRIPT: CU.

Chapter XVIII.

Galley 2d "developing independence" a phrase of double meaning. Why not growing? 
" 3 "Edw Randolph$^{1}$ was sent" \&c- There is something omitted here.

"escapade"-say offence.

"tax bills developed resistance." It does not appear to me that "developed" is the word.

" 4 "to govern the province" something omitted.

" " " "spending blood and treasure." a hackneyed phrase-say defending their homes with much loss of life and property "cases were brought" suits instead of cases.

"Losing the case" losing the suit.

5 "Mason's ${ }^{2}$ direct heirs became reduced" Reduced in what? say in fortune.

" " "affiliated in dialect" affiliated from filius implies derived, which may not have been so-you mean speaking a kindred dialect.

" " "displaying efficacy" convincing him of the efficacy.

" " "raiding"- Raid is a word of new introduction, very convenient-but raiding is detestable, and without authority

"surrender up—why $u p$ ?

6 "barbarous fashion" fashion is almost grotesque say manner. "treaty based upon"-it was more than based upon providing for

Galley 6 "raiding" again

" " "sacked the cargo"—-destroyed — You may sack a town—but not a bag of meal.

[Volume II] Chapter XVIII MaNUSCRIPT: CU.

1. Edward Randolph (1632-1703), British agent in charge of North American customs, 1678-1703, passim.

2. Captain John Mason (d. 1635), British soldier and early grantee, with Sir Fernando Gorges (1566?-1647), of New Hampshire lands.

\section{Chapter XIX}

Galley 1st "supernatural fancies"-The fancies are not supernatural but relate to things supernatural.

"fourteen old women were executed." I think the reader wishes to know where.

" " Matthew Hale a devout believer-in witchcraft?1

" " "trials came off," a phrase of the cockpit and boxing ring-for took place or was had

" 2d In the note. "Go against Scripture even so far as the above"-say "could go no further than this" 
" " "could ever fill the mould of so much cruelty the forms" \&cc Please look at these metaphors and see whether they are quite right.

"hung" for hanged

"transpiring" only means coming to light-it is here used for taking place.

"Those other children" What children[?]

"It had never been harmonious" say Its people \&c.

"She had a good deal" \&c Who had? Mary Car[r] or her Sister Ann? ${ }^{2}$ I cannot tell.

"left," for left the parish.

"tenacious man" for obstinate.

3 "They had learned from Cotton Mather"3_say according to Cotton Mather"

"provisional realities" this phrase conveys no idea to my mind.

Galley 3 "His wife was strongly opposed to that"- rather clumsy "forfeiture of a witch's property"-witch for one who practices witchcraft-but witch is always feminine

" " "threw up his seat" Not exactly so. He resigned his office.

" 4 "posing the figure." posing is technical for taking a studied attitude

" " "Maladroit" is a French word-ill-judged? indiscreet?

"ganglionic centres" better centres of nervous action-but I would rather see the whole sentence omitted.

5 "no epidemic [prevailed?]"- Epidemic is in its ordinary acceptance a disease- Here it requires the addition of delusion or the like.

"locality" a geological or numerological term for place, which is ordinarily better

"uncanny" a word not yet naturalized

I think it appears in another place in this chapter.

"an object for those"-desirable?

In the third Galley near the bottom is the clause "where the saintly Burroughs found his last resting place." The reader naturally asks himself- What is this about Burroughs? ${ }^{4}$ and looks back to find what it means. But there should be interposed the word afterward-or whose fate will hereafter be related.

Remarks on Chapter 19.

Page 229 near the top "an alarm x x that the Dutch" \&c. It seems to [me] that we cannot say "an alarm that a thing is to be done" we may say an alarming report or the like 
231 "for denouncing the Dutch for conspiring"-ill sounding at least. Lines 20 \& 21 from top.

232 End of paragraph "both" should be "each." Line 26 from top, "She now offers whom She agrees and insisted should be" false syntax.

251 "Worms and insects" should it not be "worms and other insects"?

[Volume II] Chapter XIX MANUSCRIPT: CU.

1. Sir Matthew Hale (1609-1676), British judge, legal scholar, and member of parliament, who presided at the trials of accused witches in seventeenth-century England.

2. Ann Carr (Mrs. Thomas Putnam) testified against persons accused of witchcraft in Salem, Massachusetts in the 1690s. Mary was the wife of the first minister of Salem, James Bayley.

3. Cotton Mather (1662/1663-1727/1728, Harvard B.A. 1678, M.A. 1681), Puritan clergyman and voluminous writer, who defended witchcraft convictions in his book, Wonders of the Invisible World (Boston, 1693).

4. The Reverend Stephen (or George?) Burroughs, convicted of witchcraft and hung at Salem in 1692.

Galley 1 from political reasons-say for?

" " "present proprietors"-proprietors at that time?

" " "Achtor Col." I do not understand

" " "northeast of a line" lying northeast?

" 3 "Rear Admiral of Ireland at twenty three" say years of age?

" " "come into contact with the Friends" It seems to me that this expression "contact" might be bettered- See below also.

" " "stay away from worship from his love" \&cc because of his love $\& c$ ?

" $\quad$ In a fit of temper-temper may be good or ill-say fit of anger.

" 4 "distinguished himself from the ordinary costume" He did not do this-but undoubtedly wore the costume of the Friends of that day-which Mrs. Howitt in speaking of Penn ${ }^{1}$ says he dressed like other gentlemen of the timeThe cut was probably the same only a certain plainness was observed. But why say distinguished himself from costume? "given a verdict in law" What does this mean?

"short period of his life recurred." Is this right?

5 "This was an exaction of Chief Justice North"2 The meaning is here likely to be mistaken. It was not North who required that murder \& treason only should be punishable with death. 
Galley 5 “overjoyed Quakers" why overjoyed I do not see.

" 6 "had its seat across the Alleganies." Does this mean beyond? If not I do not understand it

" 7 "sparkled with sincerity from his belief? because of his belief?

" 8 proprietaryship is an awkward word Is there none better?

[Volume II] Chapter XX MANUSCRIPT: CU.

1. The British writer Mary (Botham) Howitt, Popular History of the United States (1859). William Penn (1644-1718) was a British Quaker and founder in 1681 of Pennsylvania.

2. Francis North, first Baron Guilford (1637-1685), British chief-justice of common pleas, 1675-1682, and author of the Pennsylvania charter in 1681 .

\section{Remarks on Chapter X.Y.Z.}

This seems a chapter of less interest than those which immediately preceded it. It is a chronicle-for the most part-of petty hostilities without result.

Page 402 "Seaboard" is a newspaper term for sea coast.

"After" is beginning to be used as a preposition solelywhich seems to me a tendency worthy to be encouraged

" 404 "Governor." I have given a capital letter.

" 406 "they attacked the Tomoquas"' Who attacked them is not said.

"reduced into slavery" say "to slavery"

Pençacola. It seems to me that it were better not to say how the Spaniards formerly spelled the name the $\mathrm{c}$ with the cedilla so ç is never now used in Spanish.

" 407 "granted commissions to persons" Of course it was to persons- Strike out "to persons."

" 407 "and were routed in confusion." Who were routed-apparently and grammatically the Creeks²-but that is not meant. If they or any other tribe were routed does that not imply confusion?

" 410 "unconquered Chickesaws." verted commas. Why does not appear nor is there the least clue to a solution of the question.

" 412 "left" for left the place.-after for afterward.

" 415 Vasquez de Coronado ${ }^{4}$ is a Spanish name and should not have the Italian preposition $d i$ but $d e$.

“Chapter X. Y. Z.” [Volume II, Chapters XXII and XXIII] MaNUSCRIPT: CU.

1. A Christian Indian tribe friendly to the Spanish colonists of Florida.

2. A confederation of Indian tribes inhabiting the southeastern United States. 
3. An Indian tribe centered in Mississippi and Alabama.

4. Francisco Vasquez de Coronado (1510-1554), Spanish explorer of the American southwest in 1540-1542.

Chapter Y.

Page 305 I have made here a little change in the connectives.

Page 306 "Victor Amadee"-should it not be Amadeo the Italian ending? 1

Page 307 More changes in the particles.

"wash the Slate" a local and provincial phrase-almost slang and would not be understood every where-I would omit it.

311 "Garonne" why put in Italics?

313 "francs was" should it not be were?

it. I substitute "company" for clearness sake. "[action names?]"-why not stockholders.

316 "The cassine"- the name being Latin should be put in Italics.

" 316 "walnut tree" Is this the hickory?

" 319 "appointed a detail"-a military phrase I suppose but strictly technical-say, sent a detachment or something of the sort.

" 320 "be done" good old English is "have done"-perhaps it were better to say "get rid."

" 322 "Alas!" The exclamation were better out.

" " "A Puant chief" It seems to me that some explanation of who the Puants were should follow the name. ${ }^{2}$

" 328 "narrate" Is not "relate" better?

" 329 "dreaded enemy"- - who it was is not clear.

-The word "voyageurs" is somewhere in the chapter. It seems to me that it should be put in Italics and explained thus- "Agents of the traders with the Indians"

Chapter Y. [Volume II, Chapter XXII] MANUSCRIPT: CU.

1. Victor Amadeo II (1666-1732), Duke of Savoy.

2. The Puant Indians inhabited the area around present-day Green Bay, Wiscon$\sin$.

Chapter Z. Y. X. [xxiv]

It seems to me that this chapter shows great research-and I am almost ashamed that I can do nothing but point out a few verbal changes which seem to me proper to make-

Page 427 "Cabeça de Vaca" The word Cabeza signifying "head" is never written now with a ç but with a z.- 
Page 432 a transposition for clearness' sake

433 "inscriptions"- better engraved.

" 436 "in command in Mexico;" ill-sounding who commanded $\& c c$ ?

" 437. When Loretto is transplanted from Italy to Spain it becomes always Loreto.

"hominy"- why should the word have inverted commas? It is a good word and no quotation.

439 "Loretto" again

441 "Section." It seems to me that the good old word quarter is much better.

" 443 "pinceria" needs no quotation marks, in the history being the regular name of a place

444 Same.

445 "says the historian" Would not a note be well, naming the historian \&cc?

449 "Don Martin d'Alarconne." The name of a Spaniard must be wrong-being Frenchified. d' with the elision is not used in Spanish nor have they a double $n$.

Page 434 A like doubling of the $\mathrm{n} n$ the name of Sebastian Rodriguez Cermennon. Probably it should be Cermeñon.-1

Chapter Z. Y. X. [Volume II, Chapter XXIV] manuscriPT: CU.

1. Spanish sea captain whose ship was lost off the coast of California in 1595.

2541. To the Editors of SCRIBNER's MonThLY

New York, December 5th [1877]

... I have every disposition to comply with your request, ${ }^{1}$ but my time of life is in the way. It is now the December of the year; it is with me the December of life. Who looks for Japan lilies and heliotropes when the ground is stiff with frost? If you were to go out into the garden on such an errand, your friends might desire to make you acquainted with the commissioner of lunacy. I will bear your application, however, in mind, and if I find a stray marigold in bloom, which I do not expect, I will send it. . . .

MANUSCRIPT: Unrecovered TEXT (partial): Life, II, 388.

1. Apparently a request for verse.

2542. To Fanny Bryant Godwin

Dear Fanny.

Roslyn, L.I. Dec. 7th 1877.

There was no objection to signing the paper to which you refer ${ }^{1}-$ save that as I thought I had told you-it seemed to me better that 
there should be a separate reservoir on your land and that might require some modification of the paper already drawn up. But if the idea of another reservoir is to be given up we will have the paper signed immediately-

Affectionately \&cc

W. C. BRyANT

MANUSCRIPT: NYPL-GR ADDRESS: Mrs. F. B. Godwin.

1. Unidentified.

2543. To Julia S. Bryant

Dec. 8th 1877

Office of the Evening Post.

Dear Julia

I am so comfortable at Roslyn that I go back this evening-a little sorry that you do not come out and more sorry that you have such a cold.

Mr. Cline desired me to say to you that he could not send any thing to you to-day for the reason that the steamer made but a short stay last evening at Roslyn and went down to Glenwood.

I think I will accept Mrs. Olmsted's Invitation- Will you let her know it?

Yours affectionately

W C BRYANT

MANUSCRIPT: BLR ADDRESS: Miss Julia S. Bryant.

1. It will be recalled that Mary Bryant Olmsted, Mrs. Frederick Law Olmsted (406.4), had been Frances Bryant's godchild, and that she and Julia were nearly the same age.

2544. To Christiana Gibson

Roslyn, December 10th [1877]

... I thank you for the good wishes with which you greet my birthday. ${ }^{1}$ I have certainly no objection to see a few more birthdays yet. As long as one's bodily and mental faculties are in pretty good preservation, and no disease is present, and no disgrace has fallen on one's character, life is a great blessing. I am grateful, for my part, for the easy and comfortable old age which has fallen to my lot. I heard two days since from Mr. Richard $\mathrm{H}$. Dana, who has lately reached his ninetieth birthday, and whose mental faculties are in perfect preservation. He referred, in a letter which I had from him not long since, to an illness 
which he had suffered; but, on inquiry, I found that it was only a fall down a flight of stairs, in consequence of which he was laid up for some weeks. I am surprised that it has left him so strong, both in mind and body. When Rogers, the poet, ${ }^{2}$ was thrown out of his carriage and disabled, his mind began to suffer, for he could take no bodily exercise, and he lost his memory. Something like this happened to Josiah Quincy, who died at the age of ninety two, and was a remarkably active and well-preserved old gentleman till he was disabled by being thrown from a carriage. What renders Mr. Dana's longevity a little curious is that he has all along been haunted by the apprehension that his life would be a short one. Emerson, they say, begins to feel the decays of age not only in physical but mental infirmity. It was given out last spring that he would make no more speeches in public, and now his memory fails sadly. ... ${ }^{3}$

MANUSCRIPT: Unrecovered TEXT (partial): Life, II, 387-388.

1. Greeting unrecovered.

2. Samuel Rogers (238.2).

3. Ralph Waldo Emerson, then seventy-four, was nine years younger than Bryant. When William $H$. Channing visited Emerson in the summer of 1877, he "found that his host could not even remember [Amos Bronson] Alcott's name and noticed that he asked where Henry Thoreau [d. 1862] was when he wanted the name of a plant he had known from youth but had now forgotten." Ralph L. Rusk, The Life of Ralph Waldo Emerson (New York: Scribner's, 1949), p. 491.

2545. To Thomas L. James ${ }^{1}$

My dear sir.

The Evening Post, Broadway and Fulton Street. New York, Dec. 181877.

The bearer of this is Mrs. C. S. Wilson, who was greatly serviceable by her charities to the Union prisoners at the South during the late Civil War as is attested by the certificates of Generals Grant Sherman and Ingalls. ${ }^{2}$ She writes a rapid and legible hand and if a place could be given her in the New York post office where she could superscribe letters or do some such work it would in my opinion be only a fitting acknowledgment of what she had done for the country.

\section{I am sir with great regard}

$$
\text { Yours truly W C BRYANT }
$$

MANUSCRIPT: RBHL ADDREss: To Thomas L. James Esquire / Postmaster of New York.

1. Thomas Lemuel James (1831-1916) was a newspaper publisher, businessman, and postmaster of New York City, 1873-1881. He was briefly but effectively Postmaster General of the United States in 1881 under President Garfield. 
2. Rufus Ingalls, a West Point graduate, had been Quartermaster General of the Army of the Potomac under Generals McClellan and Hooker. Mrs. Wilson has not been further identified.

2546. To Bronson C. Keeler ${ }^{1}$

New York, $c$ December 20 [1877]

. . . By inspiration, which is the subject of your inquiries, I take for granted that you mean poetic inspiration, or the state of mind in which poetry of a high order is produced; that exaltation of the faculties in which high thoughts come into the mind and clothe themselves in apt words. I answer your questions in their order:

First. I cannot say that in writing my poems I am directly conscious of the action of an outside intelligence on my mind, but I sometimes wonder whence the thoughts come, and they seem to me hardly my own. Sometimes in searching for that adequate expression it seems suddenly darted into my mind, like a ray of light into a dark room, and gives me a kind of surprise.

Second. I don't invoke the Muse at all.

Third. It appears to me that inspiration has no more to do with one intellectual process than another, and that, if there is such a thing, it might be present as directly in the solution of a problem of high mathematics as in a copy of verses.

Fourth. I do not think the notion of inspiration to be a relic of ignorant superstition, though superstitious notions or beliefs may be connected with it, as in the case of the Delphic and other oracles of the ancients. Holding to the doctrine that there is a world of spirit as well as a world of matter, I am not prepared to say that there cannot be a direct action of mind upon mind without the interposition of a bodily presence-....

MANUSCRIPT: Unrecovered TEXT (partial): Life, II, 386-387.

1. In this letter Bryant answers categorically a series of questions posed in a letter dated December 18 from a writer, apparently on the staff of the Chicago Times, who was planning an article on the subject of "Inspiration." NYPL-BG.

2547. To L. B. Thomas ${ }^{1}$

Dear Sir.

New York Dec. 29th 1877.

The Genealogical Notes were noticed in the Evening Post on the fourth of December. Enclosed is the slip which contains the Notice. ${ }^{2}$

Yours respectfully

W. C BRYant. 
MANUSCRIPT: CHS ADDRESS: L. B. Thomas Esq.

1. Unidentified.

2. Unrecovered.

2548. To Committee of the Williams College Alumni Association

[New York?] December [1877]

... You ask me for a few lines of verse to be read at your annual festival of the alumni at Williams College. I am ever ill at occasional verses. Such as it is, my vein is not of that sort. I find it difficult to satisfy myself. Besides, it is the December of life with me. I try to keep a few flowers in pots-mere remembrances of a more genial season which is now with the things of the past. If I have a carnation or two for Christmas, I think myself fortunate. You write as if I had nothing to do, in fulfilling your request, but to go out and gather under the hedges and by the brooks a bouquet of flowers that spring spontaneously, and throw it upon your table. If I should try, what would you say, if it proved to be only a little bundle of devil-stalks and withered leaves, which my dim sight had mistaken for fresh, green sprays and blossoms? So I must excuse myself as well as I can, and content myself with wishing a very pleasant evening to the foster-children of old "Williams" who meet on New Year's Day, and all manner of prosperity and honor to the excellent institution of learning in which they are nurtured. ...

MANUSCRIPT: Unrecovered TEXT (partial): Life, II, 388-389. 